$7-2006$

\title{
Evaluating Sedimentary Geochemical Lake-Level Tracers in Walker Lake, Nevada, Over the Last 200 Years
}

\author{
Fasong Yuan \\ Cleveland State University, f.yuan06@csuohio.edu \\ Braddock K. Linsley \\ University at Albany-State University of New York \\ Stephen S. Howe \\ University at Albany-State University of New York
}

Follow this and additional works at: https://engagedscholarship.csuohio.edu/scibges_facpub

Part of the Biology Commons

How does access to this work benefit you? Let us know!

Publisher's Statement

The final publication is available at Springer via http://dx.doi.org/10.1007/s10933-006-0004-8

\section{Recommended Citation}

Yuan F, Linsley BK, Howe SS. 2006. Evaluating sedimentary geochemical lake-level tracers in Walker Lake, Nevada, over the last 200 years. J Paleolimnol. 36(1):37-54.

This Article is brought to you for free and open access by the Biological, Geological, and Environmental Sciences Department at EngagedScholarship@CSU. It has been accepted for inclusion in Biological, Geological, and Environmental Faculty Publications by an authorized administrator of EngagedScholarship@CSU. For more information, please contact library.es@csuohio.edu. 


\title{
Evaluating sedimentary geochemical lake-level tracers in Walker Lake, Nevada, over the last 200 years
}

\author{
Fasong Yuan • Braddock K. Linsley • \\ Stephen S. Howe
}

\begin{abstract}
Walker Lake, a hydrologically closed, saline, alkaline lake located along the western margin of the Great Basin of western United States, has experienced a $77 \%$ reduction in volume and commitment drop in lake level as a result of anthropogenic perturbations and climatic fluctuations over the last century. The history of lake-level change in Walker Lake has been recorded instrumentally since 1860 . A high-resolution multi-proxy sediment core record from Walker Lake has been generated through analysis of total inorganic carbon (TIC), total organic carbon (TOC), and oxygen and carbon isotope ratios $\left(\delta^{18} \mathrm{O}\right.$ and $\left.\delta^{13} \mathrm{C}\right)$ of both downcore bulk TIC and ostracods over the last $200 \mathrm{yr}$. This allows us to examine how these sediment indices respond to actual changes in this lake's hydrologic balance at interannual to decadal timescales. In Walker Lake sediments, changes in $\%$ TIC, \% TOC, and $\delta^{13} \mathrm{C}$ and $\delta^{18} \mathrm{O}$ of TIC and ostracods are all associated to varying degrees with
\end{abstract}

F. Yuan $(\bowtie) \cdot$ B. K. Linsley $\cdot$ S. S. Howe

Department of Earth and Atmospheric Sciences,

University at Albany-State University of New York,

1400 Washington Avenue, Albany,

NY 12222, USA

e-mail: fyuan@tamu.edu

F. Yuan

Agricultural Research and Extension Center, Texas A\&M

University, 1380 A\&M Circle,

El Paso, TX 79927, USA changes in the lake's hydrologic balance, with $\delta^{18} \mathrm{O}$ of the TIC fraction $\left(\delta^{18} \mathrm{O}_{\text {TIC }}\right)$ being the most highly correlated and the most effective hydrologic indicator in this closed-basin lake. The $\delta^{18} \mathrm{O}_{\mathrm{TIC}}$ record from Walker Lake nearly parallels the instrumental lake-level record back to 1860 . However, comparison with sporadic lake-water $\delta^{18} \mathrm{O}$ and dissolved inorganic carbon $\delta^{13} \mathrm{C}$ $\left(\delta^{13} \mathrm{C}_{\text {DIC }}\right)$ results spanning the last several decades suggests that the isotopic values of downcore carbonate sediments may not be readily translated into absolute or even relative values of corresponding lake-water $\delta^{18} \mathrm{O}$ and $\delta^{13} \mathrm{C}_{\mathrm{DIC}}$. Changes in the lake's hydrologic balance usually lead to changes in isotopic composition of lake waters and downcore sediments, but not all the variations in downcore isotopic composition are necessarily caused by hydrologic changes.

Keywords Stable isotopes - Carbonate sediments . Lake level · Ostracode $\cdot$ Paleoclimate $\cdot$ Walker Lake $\cdot$ Western USA

\section{Introduction}

Paleoclimate studies have demonstrated that late Pleistocene millennial-scale climate variability first observed in the North Atlantic region is also recorded in lacustrine sediments from Great Basin lakes of western USA (Benson, 1999). As noted by Benson (1999), the Great Basin lakes provide an opportunity 
for generating high-resolution proxy records of this climatic variability given their relatively high sedimentation rates $\left(1.5-2.5 \mathrm{~m} \mathrm{kyr}^{-1}\right)$. Recent highresolution (decadal) paleoclimate reconstruction in the Great Basin region have further revealed multicentennial scale oscillations in Sierran wetness $(\mathrm{Li}$ et al., 2000; Benson et al., 2002; Benson et al., 2003; Yuan et al., 2004), and at least some of the oscillations appear synchronous with changes in other phenomena such as alternations of the California Current and variations in cosmogenic nuclide production rates (Yuan et al., 2004).

Change in the size of a closed-basin lake is considered to be representative of change in drainage basin hydrologic balance, and such changes can be recorded in lacustrine sediments. Following the early work of Stuiver and his co-workers on the $\delta^{18} \mathrm{O}$ of lake carbonates (Stuiver, 1968, 1970; Covich and Stuiver, 1974), the $\delta^{18} \mathrm{O}$ of inorganic and biogenic lake carbonates has been commonly used for paleoclimate reconstructions (Fritz and Poplawsk, 1974; Benson et al., 1991; Holmes, 1996; Benson et al., 2002; Kirby et al., 2004).

In several Great Basin lakes, studies have shown that variations in lake carbonate $\delta^{18} \mathrm{O}\left(\delta^{18} \mathrm{O}_{\mathrm{TIC}}\right)$ are directly related to changes in the hydrologic balance (Benson et al., 1991, 1996, 2002, 2003; Yuan et al., 2004). Benson et al. (1996) monitored the $\delta^{18} \mathrm{O}$ of lake water $\left(\delta^{18} \mathrm{O}_{\text {water }}\right)$ from 1985 to 1994 in Pyramid and Walker lakes. Their results indicated that the yearly variations in the $\delta^{18} \mathrm{O}_{\text {water }}$ correlated well with changes in lake volume. In addition, their $\delta^{18} \mathrm{O}_{\text {water }}$ data displayed strong seasonal variations that were attributable to monthly changes in the hydrologic balance. On multi-decadal timescales, Li et al. (1997) demonstrated that the $\delta^{18} \mathrm{O}_{\mathrm{TIC}}$ record from Mono Lake nearly paralleled its lake-level fluctuations during the last 80 years. Benson et al. (2003) also produced a high-resolution $\delta^{18} \mathrm{O}_{\mathrm{TIC}}$ record from Mono Lake sediments and illustrated that changes in $\delta^{18} \mathrm{O}_{\text {TIC }}$ values correlated with changes in lake volume. Using sediments from Walker Lake, Yuan et al. (2004) examined century-scale changes in hydrologic balance through the analysis of $\delta^{18} \mathrm{O}_{\mathrm{TIC}}$.

Although changes in lake carbonate $\delta^{18} \mathrm{O}$ have been shown to be linked to changes in the hydrologic balance of Great Basin lakes, there remain significant uncertainties with respect to translating the magnitude of $\delta^{18} \mathrm{O}_{\text {TIC }}$ variations directly into lake volume variations. Benson and Paillet (2002) have shown that even though the magnitudes of oscillation in $\delta^{18} \mathrm{O}_{\text {TIC }}$ and lake volume records may differ, both records will typically contain the same number of peaks and troughs with the oscillation in $\delta^{18} \mathrm{O}_{\mathrm{TIC}}$ lagging slightly the oscillation in lake volume.

Here we present high-resolution geochemical records from Walker Lake spanning the last $200 \mathrm{yr}$. Age controls are derived from two radiocarbon dates of organic sediment materials and further refined through correlations between the cores and to an 18-year long record of $\delta^{18} \mathrm{O}_{\text {water }}$ and to an instrumental record of lake level change since 1860 . This analysis also takes advantage of an instrumental lake-volume record and water geochemical data from Walker Lake over the last century, and high-resolution piston and box sediment cores collected in 2000, allowing us to more fully understand the specific causes of inorganic and biogenic carbonate isotopic variability in Walker Lake.

\section{Study site}

Walker Lake lies in the rainshadow of the eastern flank of the Sierra Nevada. On average, the lake receives $\sim 13 \mathrm{~cm} \mathrm{yr}^{-1}$ of direct precipitation. Approximately $90 \%$ of the moisture that reaches the lake is via the Walker River (Fig. 1). Runoff is mostly $(\sim 91 \%)$ in the form of snowmelt. Water loss occurs mainly through evaporation (average of $\sim 135 \mathrm{~cm} \mathrm{yr}^{-1}$ ) and groundwater flux into the lake is negligible (Milne, 1987). Wintertime precipitation on the Sierra Nevada is directly associated with the mean position of the polar jet stream (Riehl et al., 1954; Horn and Bryson, 1960; Ware and Thomson, 2000). Since the northern Sierra lies on a hinge node with respect to the effects of the El Niño/Southern Oscillation (ENSO), precipitation and stream discharge in this region do not correlate with the Southern Oscillation Index (SOI) although individual ENSO events can effect climate in the region (Redmond and Koch, 1991). However, streamflow records exhibit a distinct pattern of decadal variability ( $\mathrm{Li}$ and $\mathrm{Ku}, 1997 \mathrm{~b}$ ), which shares similarities with the Pacific Decadal Oscillation (PDO) (Mantua et al., 1997; Zhang et al., 1997; Mantua and Hare, 2002; Benson et al., 2003).

The hydrologic balance of the Walker River Basin has been affected by human activities since the onset 


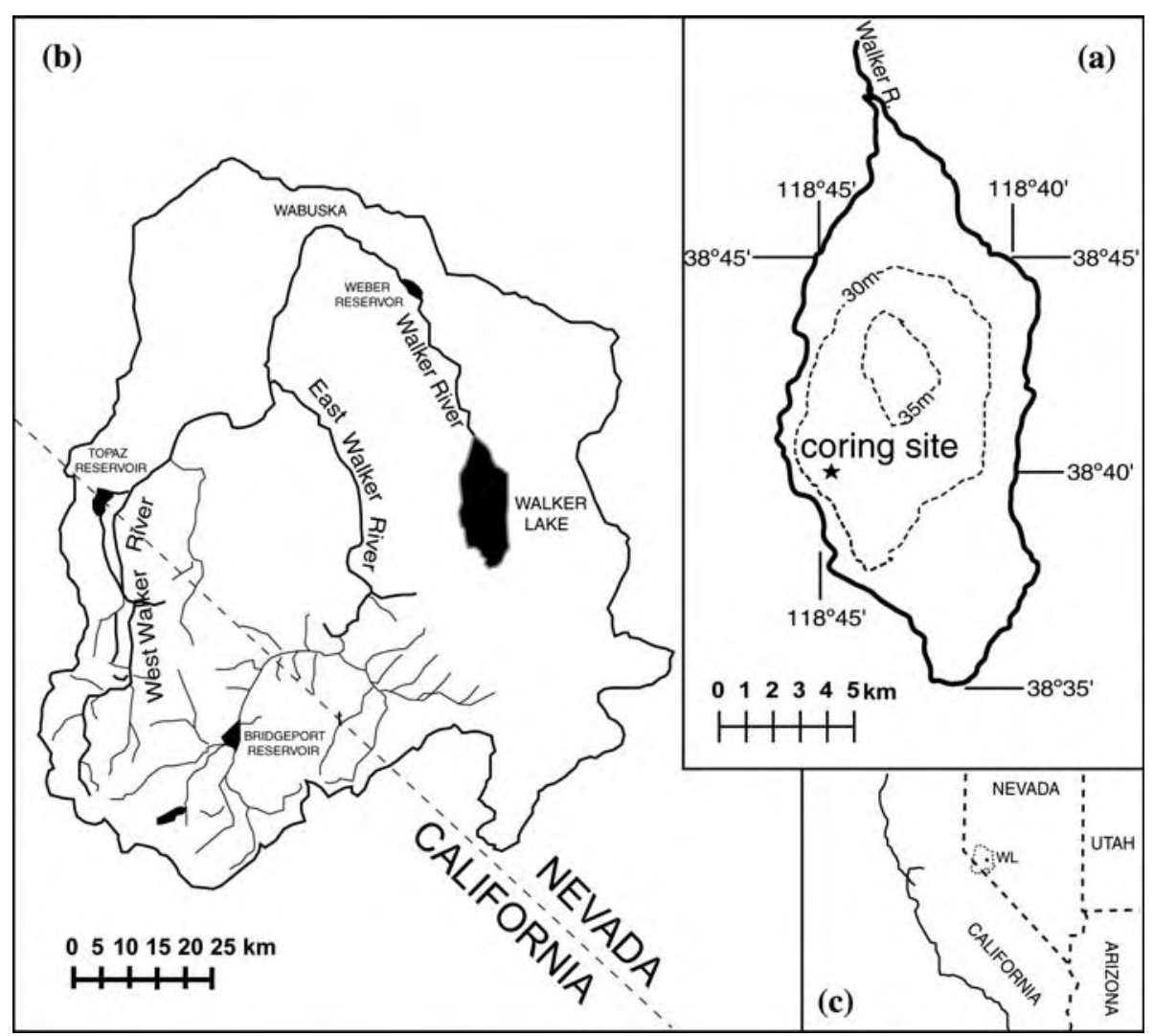

Fig. 1 Site location maps showing relevant information. (a) Bathymetric map of Walker Lake with location of coring site (Benson, 1988). (b) Drainage map showing locations of the
Walker River and Walker Lake (Benson, 1988). (c) Index map showing geographic locations of Walker Lake (WL)

Walker Lake is saline $\left(12.5 \mathrm{~g}^{-1}\right)$ and alkaline $(\mathrm{pH}=9.5)$ and its major ions are dominated by $\mathrm{Na}-\mathrm{Cl}-\mathrm{SO}_{4}-\mathrm{HCO}_{3}$ (Table 1). The total dissolved solids (TDS) concentration increased from $2.5 \mathrm{~g} \mathrm{l}^{-1}$ in 1882 to $12.5 \mathrm{~g} \mathrm{l}^{-1}$ in $1994-2004$. The $\mathrm{Mg} / \mathrm{Ca}$ molar ratio increased from $\sim 3$ in 1884 to $\sim 30$ in 1994-2004. Lake chemistry changes appear to have affected aquatic fauna in the lake. For example, the ostracode Candona caudata lived in Walker Lake prior to its drawdown beginning in the early 1920s but now has become locally extinct (Bradbury et al., 1989). Limnocythere ceriotuberosa is the only abundant ostracode that lives at the lake sediment-water interface today (Bradbury, 1987; Bradbury et al., 1989).

\section{Methods}

A $39.6 \mathrm{~cm}$ long boxcore (WLB003C) and a $\sim 480 \mathrm{~cm}$ long piston core (WLC002) were collected from the 
Fig. 2 Instrumental lakelevel record of Walker Lake back to 1860 (original data from the US Geological Survey)

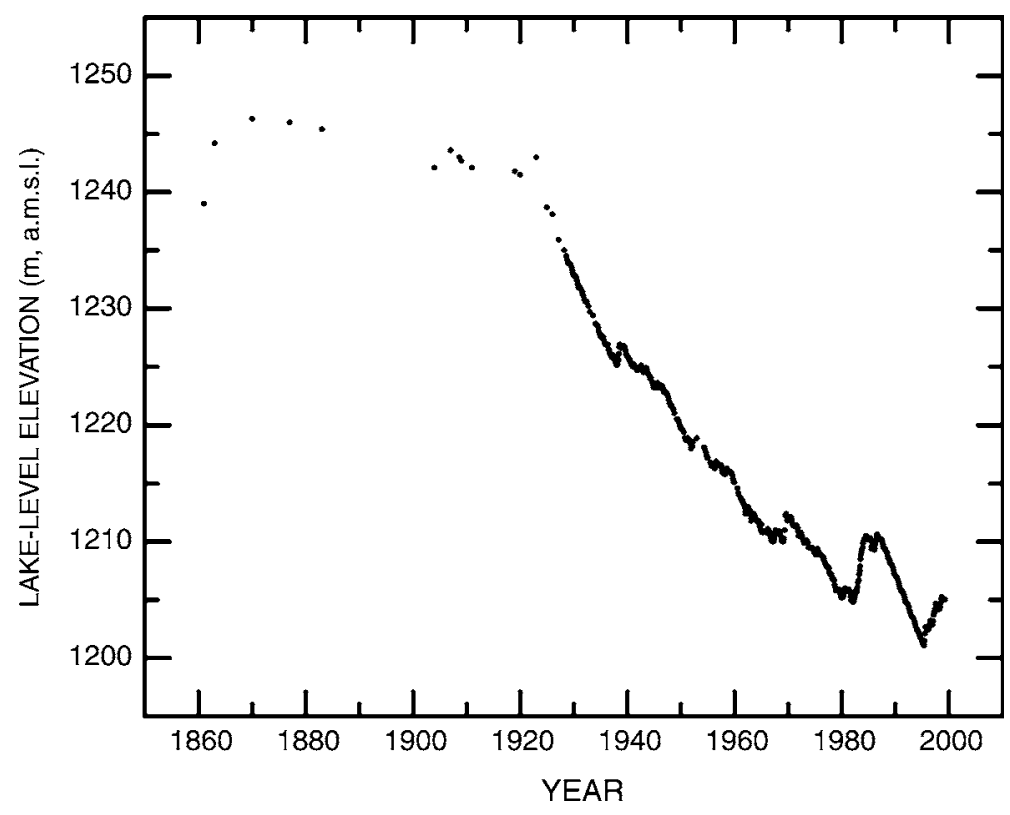

Table 1 Major element hydrochemistry of lakes and reservoirs in the Walker River Basin

\begin{tabular}{|c|c|c|c|c|c|c|c|c|c|c|c|}
\hline Sites & $\begin{array}{l}\mathrm{pH} \\
\text { S.U. }\end{array}$ & $\begin{array}{l}\mathrm{Ca} \\
\left(\mathrm{mg} \mathrm{1}^{-1}\right)\end{array}$ & $\mathrm{Mg}$ & $\mathrm{Na}$ & $\mathrm{K}$ & $\mathrm{HCO}_{3}$ & $\mathrm{CO}_{3}$ & $\mathrm{Cl}$ & $\mathrm{SO}_{4}$ & $\mathrm{SiO}_{2}$ & $\begin{array}{l}\text { TDS } \\
\left(\mathrm{g} \mathrm{l}^{-1}\right)\end{array}$ \\
\hline \multicolumn{12}{|c|}{ Topaz Reservoir } \\
\hline $1975^{\mathrm{a}}$ & 7.9 & 12 & 2.3 & 7.4 & 1.5 & 64 & - & 2.4 & 4.8 & 10 & 0.1 \\
\hline $1994-2004^{\mathrm{b}}$ & 8.4 & 12 & 3.1 & 9.9 & - & 67 & 1.9 & 3.1 & 4.9 & - & 0.1 \\
\hline \multicolumn{12}{|c|}{ Bridgeport Reservoir } \\
\hline $1975^{a}$ & 8.4 & 20 & 3.4 & 9.1 & 2.7 & 100 & - & 1.3 & 7.5 & 18 & 0.2 \\
\hline $1994-2004^{\mathrm{b}}$ & 8.5 & 16 & 3.6 & 14 & - & 84 & 7.4 & 2.3 & 13 & - & 0.1 \\
\hline \multicolumn{12}{|c|}{ Weber Reservoir } \\
\hline $1975^{\mathrm{a}}$ & 9.1 & 33 & 21 & 134 & 14 & - & - & 49 & 117 & 32 & 0.5 \\
\hline $1995-2001^{\mathrm{b}}$ & 8.5 & 31 & 7.6 & 41 & - & 164 & 5 & 16 & 48 & - & 0.3 \\
\hline \multicolumn{12}{|l|}{ Walker Lake } \\
\hline $1882^{\mathrm{c}}$ & - & 27 & 39 & 860 & - & - & 434 & 590 & 530 & 8 & 2.5 \\
\hline $1937^{d}$ & - & 24 & 66 & 1680 & - & 1590 & - & 1090 & 1090 & - & 5.6 \\
\hline $1966^{\mathrm{e}}$ & 9.3 & 4.2 & 124 & 3040 & 160 & 1640 & 486 & 2020 & 1930 & 0.5 & 8.6 \\
\hline $1975-1977^{f}$ & 9.4 & 11 & 136 & 3120 & 166 & 1790 & 560 & 2260 & 2060 & 0.7 & 10.6 \\
\hline $1994-2004^{\mathrm{b}}$ & 9.5 & 8.4 & 148 & 4002 & - & 1832 & 884 & 3020 & 2913 & - & 12.5 \\
\hline
\end{tabular}

${ }^{a}$ Benson and Spencer (1983)

b NDEP (2004)

${ }^{c}$ Russell (1885)

${ }^{\mathrm{d}}$ Miller et al. (1953)

e Rush (1970)

${ }^{\mathrm{f}}$ Cooper and Koch (1984)

western side of Walker Lake in June 2000 (Fig. 1a). The coring platform and methods have been described elsewhere (Benson et al., 2003). A nearly intact watersediment interface was obtained from WLB003C.
Core WLB003C was extruded vertically and sectioned at $0.5-\mathrm{cm}$ intervals while core WLC002 was split lengthwise and sampled at $1-\mathrm{cm}$ intervals. Samples were washed, oxidized with a $2.6 \% \mathrm{NaClO}$ solution, 
rinsed with deionized water, and oven-dried at $60^{\circ} \mathrm{C}$ for coulometric and isotopic analyses (Yuan, 2003).

Since the ostracode $C$. caudata was only present in core WLB003C below a depth of $28 \mathrm{~cm}$, for isotopic analysis the ostracode $L$. ceriotuberosa was handpicked under binocular microscope, washed in deionized water, and oven-dried at $60^{\circ} \mathrm{C}$. Approximately 10-15 shells (including adults and juveniles) from each sample were combined for each stable isotopic analysis.

Total carbon (TC) and total inorganic carbon (TIC) were measured on bulk samples using a coulometer equipped with acidification and combustion devices (Engleman et al., 1985). The detection limit was $0.08 \% \mathrm{C}$, the standard deviation for standard carbonate materials was $\sim 0.1 \%$, and the relative error of replicates was $<2.0 \%$. Total organic carbon (TOC) was determined by the difference between TC and TIC.

Carbon and oxygen isotopic analyses of both ostracodes and bulk TIC were performed on a Micromass Optima mass spectrometer with a MultiPrep automated sample preparation device (Yuan, 2003). The isotopic results were reported relative to Vienna Peedee Belemnite (VPDB) standard, based on working standards calibrated against NBS-19. In this paper, we use $\delta^{18} \mathrm{O}_{\mathrm{TIC}}$ and $\delta^{13} \mathrm{C}_{\mathrm{TIC}}$ to stand for oxygen and carbon isotope composition of bulk TIC, and $\delta^{18} \mathrm{O}_{\mathrm{OST}}$ and $\delta^{13} \mathrm{C}_{\mathrm{OST}}$ to represent oxygen and carbon isotope composition of ostracode (L. ceriotuberosa) shells. The overall precision of $\delta^{13} \mathrm{C}$ and $\delta^{18} \mathrm{O}$ for standard materials was $0.02 \%$ and $0.04 \%$, respectively. Based on the analysis of 12 replicate samples, the mean relative errors of $\delta^{13} \mathrm{C}_{\mathrm{TIC}}$ and $\delta^{18} \mathrm{O}_{\mathrm{TIC}}$ were 0.5 and $2.8 \%$, respectively.

\section{Analytical results}

The sediments consist of massive clay, marl deposits, and carbonates, including ostracode shells and other plant remains. Examination of the ostracode fauna reveals that $C$. caudata is absent in WLB003C above a depth of $28 \mathrm{~cm}$. L. ceriotuberosa is present throughout the boxcore, but its shell size becomes smaller near the core top.

Measurements of both TOC and TIC from core WLB003C vary from 1 to $5 \% \mathrm{C}$ (Fig. $3 \mathrm{a}, \mathrm{b}$ ). The TIC record displays a trend of progressively increasing TIC downcore, whereas the TOC record shows a nearly opposite trend that is interrupted by three intervals of lower TOC centered at depths of 15,8 , and $2 \mathrm{~cm}$. TOC is negatively correlated with TIC ( $r=-0.63, n=78)$.

Measurements of $\delta^{13} \mathrm{C}_{\mathrm{TIC}}$ and $\delta^{18} \mathrm{O}_{\mathrm{TIC}}$ from core WLB003C exhibit relatively large variations ranging from -4 to $4 \%$ (VPDB) and 1 to $4 \%$ (VPDB) respectively (Fig. 3c, d). Beginning at the bottom of the box core, the $\delta^{18} \mathrm{O}_{\mathrm{TIC}}$ values increase by $4.3 \%$ between 39 and $35 \mathrm{~cm}$ and become more stable between 35 and $15 \mathrm{~cm}$. In the topmost $15 \mathrm{~cm}$ the $\delta^{18} \mathrm{O}_{\text {TIC }}$ curve indicates a relatively large $(1.5-2.0 \%$ o negative excursion with increased variability. The $\delta^{13} \mathrm{C}_{\mathrm{TIC}}$ record exhibits a similar pattern of variability and is correlated with the $\delta^{18} \mathrm{O}_{\mathrm{TIC}}$ data $(r=0.79, n=79)$.

The $\delta^{13} \mathrm{C}$ and $\delta^{18} \mathrm{O}$ values of $L$. ceriotuberosa shells from core WLB003C also show relatively large variations (Fig. 3e, f). The $\delta^{18} \mathrm{O}_{\mathrm{OST}}$ is weakly correlated with $\delta^{13} \mathrm{C}_{\mathrm{OST}}(r=0.3, n=39)$ but is positively correlated with $\delta^{18} \mathrm{O}_{\mathrm{TIC}}(r=0.6, n=39)^{1}$. The $\delta^{18} \mathrm{O}_{\mathrm{OST}}$ data display a small negative excursion centered at a depth of $\sim 10 \mathrm{~cm}$. The ostracode shells are generally enriched in ${ }^{18} \mathrm{O}$ and depleted in ${ }^{13} \mathrm{C}$ compared to the bulk inorganic carbonates (Table 2).

The $\delta^{18} \mathrm{O}_{\text {TIC }}, \delta^{13} \mathrm{C}_{\mathrm{TIC}}$ and \% TIC results from the upper $70 \mathrm{~cm}$ of core WLC002 show a larger range of variations relative to core WLB003C (Fig. 4). The $\delta^{18} \mathrm{O}_{\text {TIC }}$ is positively correlated with \% TIC and $\delta^{13} \mathrm{C}_{\mathrm{TIC}}(r=0.74, n=71)$. The base sediments of WLC002 contain low \% TIC with more negative values of $\delta^{13} \mathrm{C}_{\text {TIC }}$ and $\delta^{18} \mathrm{O}_{\text {TIC }}$. Such low \% TIC with abnormal $\delta^{13} \mathrm{C}_{\mathrm{TIC}}$ and $\delta^{18} \mathrm{O}_{\mathrm{TIC}}$ recurs at a depth of $55 \mathrm{~cm}$. Both $\delta^{18} \mathrm{O}_{\text {TIC }}$ and \% TIC records exhibit distinct transitions at a depth of $\sim 28 \mathrm{~cm}$, which as discussed below is likely associated with the anthropogenic lowering of Walker Lake in the 1920s.

Figure 5 compares the $\delta^{18} \mathrm{O}_{\mathrm{TIC}}$ records from WLB003C with the data from the upper $70 \mathrm{~cm}$ of WLC002. Core WLC002 has relatively low apparent sedimentation rates compared to core WLB003C possibly due to the different coring methods used. Comparison of the $\delta^{18} \mathrm{O}_{\mathrm{TIC}}$ records from WLB003C and WLC002 suggests that there is only trivial sediment loss at the top of core WLC002. The $\delta^{18} \mathrm{O}_{\mathrm{TIC}}$

\footnotetext{
${ }^{1}$ Correlation was estimated on the interpolated data due to different resolution of the two records.
} 


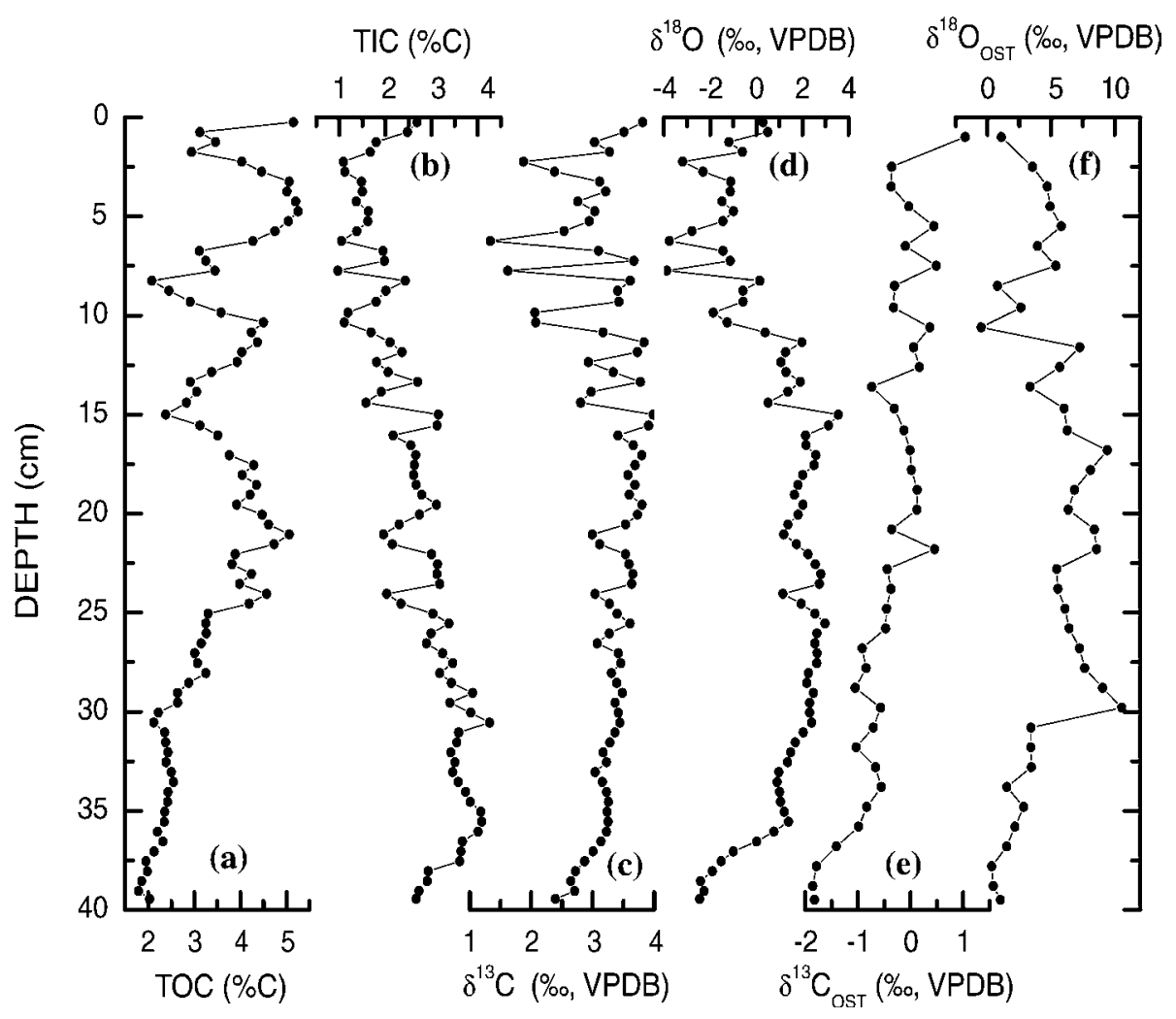

Fig. 3 Downcore variations in isotopic and geochemical indices for core WLB003C. (a) Total organic carbon (TOC). (b) Total inorganic carbon (TIC). (c) $\delta^{13} \mathrm{C}$ of bulk inorganic fraction $\left(\delta^{18} \mathrm{O}_{\mathrm{TIC}}\right)$. (e) $\delta^{13} \mathrm{C}$ of ostracode L. ceriotuberosa shells $\left(\delta^{13} \mathrm{C}_{\mathrm{OST}}\right)$. (f) $\delta^{18} \mathrm{O}$ of ostracode L. ceriotuberosa shells $\left(\delta^{18} \mathrm{O}_{\mathrm{OST}}\right)$

Table 2 Statistics of isotopic ratios of waters and sediments in the Walker River and Lake

\begin{tabular}{|c|c|c|c|c|c|c|}
\hline & Period & Min & Max & Mean & $1-\sigma$ & $\mathrm{N}^{\mathrm{a}}$ \\
\hline \multicolumn{7}{|l|}{ Water $\left(\delta^{18} \mathrm{O}, \mathrm{SMOW}\right)$} \\
\hline River & $1984-1986^{\mathrm{b}}$ & -15.8 & -10.8 & -13.8 & 1.05 & 28 \\
\hline Lake & $1985-1994^{\mathrm{c}}$ & -2.9 & 2.0 & 0.2 & 1.44 & 76 \\
\hline \multicolumn{7}{|l|}{ Sediments $\left(\delta^{18} \mathrm{O}, \mathrm{VPDB}\right)$} \\
\hline Inorganic carbonates & $1985-1994^{\mathrm{d}}$ & -3.9 & 0.2 & -1.7 & 1.28 & 11 \\
\hline Ostracodes & $1985-1994^{\mathrm{e}}$ & -0.8 & 5.8 & 4.3 & 1.81 & 6 \\
\hline \multicolumn{7}{|l|}{ Water $\left(\delta^{13} \mathrm{C}, \mathrm{VPDB}\right)$} \\
\hline Lake (DIC) & $1991-1994^{\mathrm{c}}$ & 1.6 & 2.4 & 2.1 & 0.19 & 37 \\
\hline \multicolumn{7}{|l|}{ Sediments $\left(\delta^{13} \mathrm{C}, \mathrm{VPDB}\right)$} \\
\hline Inorganic carbonates & $1991-1994^{\mathrm{d}}$ & 2.8 & 3.2 & 3.0 & 0.19 & 4 \\
\hline Ostracodes & $1991-1994^{\mathrm{e}}$ & -0.4 & 0.4 & 0.0 & 0.41 & 3 \\
\hline
\end{tabular}

${ }^{\mathrm{a}} \mathrm{N}$ stands for number of samples taken

b Benson (1988)

${ }^{\mathrm{c}}$ Benson et al. (1996)

d This study based on measurements of bulk inorganic carbonates from WLB003C

e This study based on measurements of ostracode shells (L. ceriotuberosa) from WLB003C 


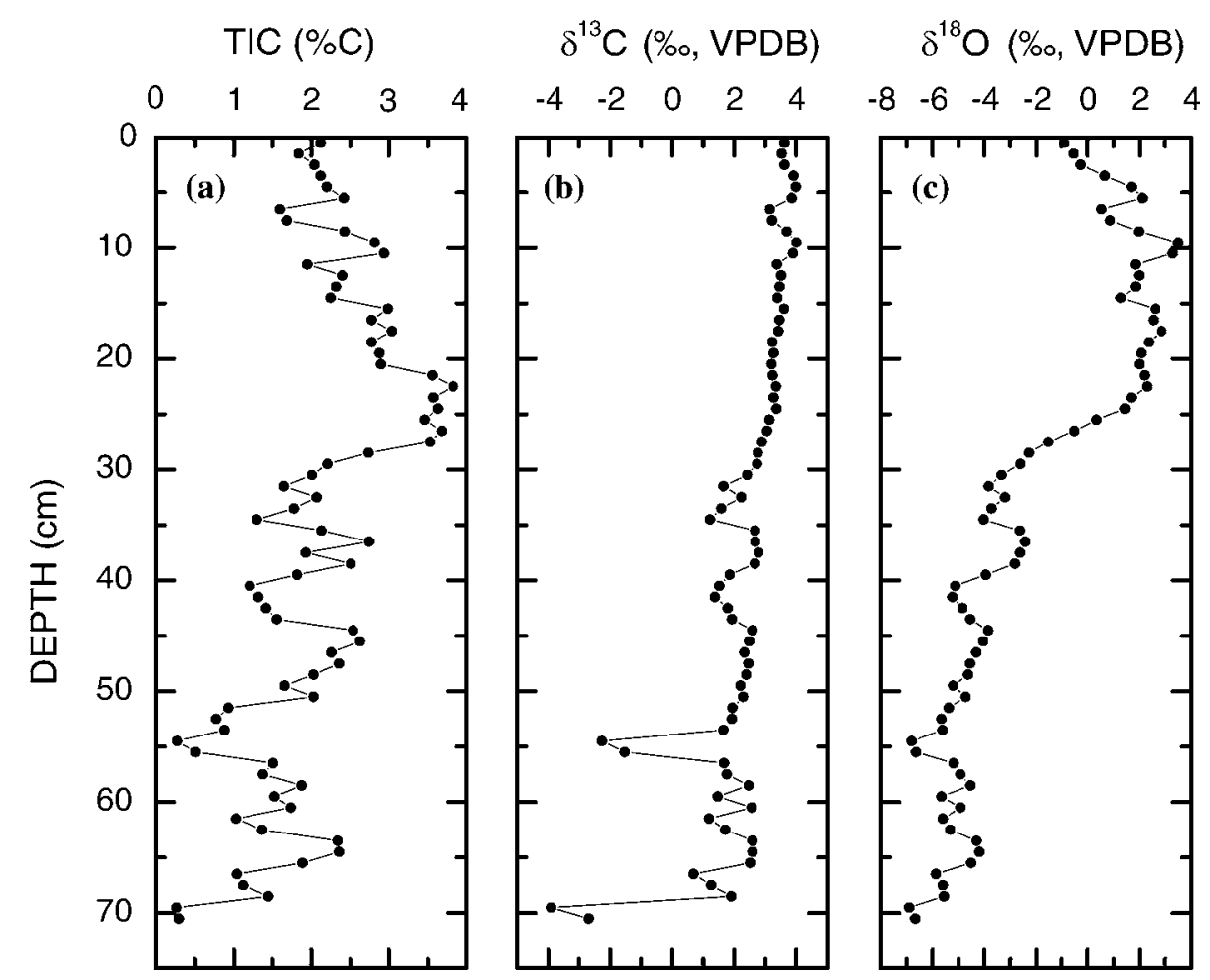

Fig. 4 Downcore variations in isotopic and geochemical indices for core WLC002. (a) Total inorganic carbon (TIC). (b) $\delta^{13} \mathrm{C}$ of bulk inorganic carbon fraction $\left(\delta^{13} \mathrm{C}_{\mathrm{TIC}}\right)$. (c) $\delta^{18} \mathrm{O}$ of bulk inorganic carbon fraction $\left(\delta^{18} \mathrm{O}_{\mathrm{TIC}}\right)$

results from the two cores are strongly correlated, as highlighted by the horizontal dashed lines (Fig. 5), indicating that the 2 cores temporally overlap.

\section{Age controls}

In the top $70 \mathrm{~cm}$ of core WLC002 two radiocarbon ages were determined through analysis of the total organic fraction at the Center of Accelerator Mass Spectrometry (CAMS), Lawrence Livermore National Laboratory (LLNL), Livermore, California. The age model for the entire core is based on 9 radiocarbon dates and is presented in Yuan et al. (2004). The two radiocarbon ages in this section of the core are subject to correction due to the known reservoir effect of $\sim 300$ yr (Broecker and Walton, 1959; Benson et al., 1991; Yuan et al., 2004) and corresponding calendar ages were estimated through Table 2 in Stuiver et al. (1998) (Table 3). A Hg record derived from other cores in Walker Lake also indicates the sediment age at a depth of $40 \mathrm{~cm}$ is close to $1900 \mathrm{AD}$ (Yuan et al., 2004).
As stated above, an $18-\mathrm{yr} \delta^{18} \mathrm{O}_{\text {water }}$ record from Walker Lake was previously discussed (Benson, 1988; Newton and Grossman, 1988; Benson et al., 1991, 1996). Comparison of the $\delta^{18} \mathrm{O}_{\text {water }}$ record with the $\delta^{18} \mathrm{O}_{\mathrm{OST}}$ record from WLB003C indicates that the age of sediments at $9 \mathrm{~cm}$ depth is $\sim 1986$ (Fig. 6). Given the strong intra-core correlations (Fig. 5), this age constraint can be transferred into age of the sediments at a depth of $\sim 4 \mathrm{~cm}$ in core WLC002. The uncertainty of the age transfer between the two cores is estimated to be within \pm 5 yr. The age model for WLC002 is derived, year $=1992.4-1.5269$ depth $-0.01896 \mathrm{depth}^{2}$, using a second-order polynomial fitting (Fig. 7a). This age model indicates a $\sim 8$-yr sediment loss at the top of core WLC002 during core recovery. This age model indicates that the beginning of the $\delta^{18} \mathrm{O}_{\mathrm{TIC}}$ transition to higher $\delta^{18} \mathrm{O}$ at $\sim 32 \mathrm{~cm}$ occurred in the early 1920s, in line with the timing of major reservoir construction in the drainage basin.

The base age of core WLB003C is inferred to be in $\sim 1932$ based on the WLC002 age model and the intra-core correlations (Fig. 5), and the top age is 


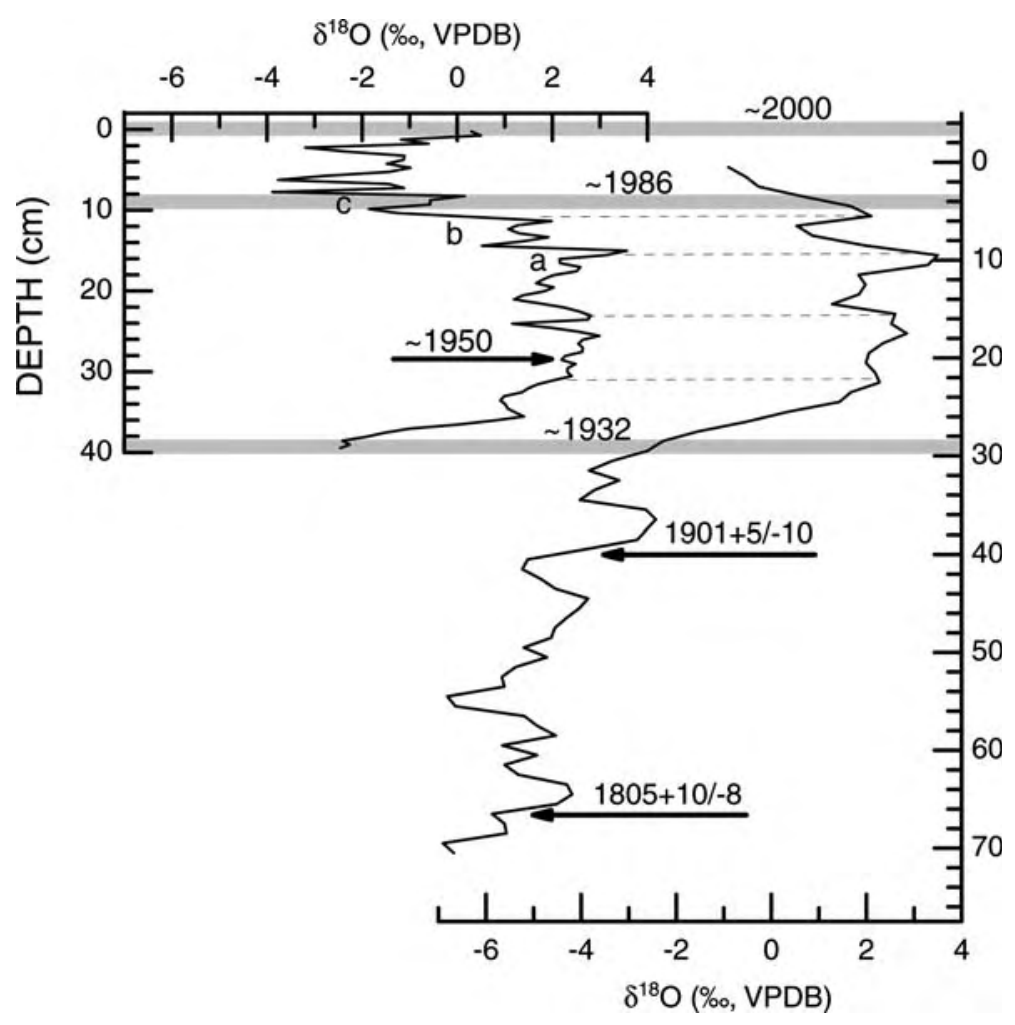

Fig. 5 Intra-core correlations of $\delta^{18} \mathrm{O}_{\mathrm{TIC}}$ records from WLB003C (left) and WLC002 (right). Solid arrowed lines denote quantitative and semi-quantitative sediment ages derived from the radiocarbon dating of organic materials and the biomarker of ostracode species. The ostracode $C$. caudata became locally extinct at and above depth $\sim 28 \mathrm{~cm}$, which occurred sometime after dam constructions in 1923 (Bradbury et al., 1989). Horizontal dashed lines highlight correlations of the two $\delta^{18} \mathrm{O}_{\mathrm{TIC}}$ records. Three horizontal gray bars denote

assumed to be in 2000 because the sediment-water interface was retained during core recovery. The age model for WLB003C is showed in Fig. 7b through linear fitting, year $=2000.79-1.75779$ depth. This age model places the last appearance of $C$. caudata at $\sim 1950 \mathrm{AD}$, in agreement with the observation of Bradbury et al. (1989). inferred age controls for WLB003C. The age of the topmost sediments is assumed to be modern (i.e., 2000), as the sediment-water interface was retained during core acquisition. The second age control is derived from correlations between $\delta^{18} \mathrm{O}_{\mathrm{OST}}$ and lake water $\delta^{18} \mathrm{O}$ records (ref. Fig. 6). This age constraint is also used for age model of core WLC002. The last age control for WLB003C is inferred from the age model of WLC002 (ref. Fig. 7a), which is estimated to be about 1932

The average sedimentation rates for WLC002 and WLB003C are $\sim 3.5$ and $5.7 \mathrm{~mm} \mathrm{yr}^{-1}$. The sedimentation rate of boxcore $\mathrm{WLB} 003 \mathrm{C}$ is similar to that of cores taken from Mono Lake, e.g., 4.0 $7.5 \mathrm{~mm} \mathrm{yr}^{-1}$ based on ${ }^{210} \mathrm{~Pb}$ data (Jellison, 1996; Li et al., 1997) and $5.1 \mathrm{~mm} \mathrm{yr}^{-1}$ using $\delta^{18} \mathrm{O}$ and lake volume data (Benson et al., 2003).

Table 3 Radiocarbon dates from Walker Lake

\begin{tabular}{|c|c|c|c|c|c|}
\hline \multirow{2}{*}{$\begin{array}{l}\text { CAMS } \\
\text { Lab \# }\end{array}$} & \multirow[t]{2}{*}{ Depth $(\mathrm{cm})$} & \multicolumn{2}{|c|}{ Radiocarbon age $^{\mathrm{a}}$} & \multicolumn{2}{|c|}{ Calibrated age $^{b}$} \\
\hline & & $(14 \mathrm{C}$ yr BP) & Error $( \pm \mathrm{yr})$ & (Cal yr AD) & Error $( \pm \mathrm{yr})$ \\
\hline 87139 & 40 & 345 & 35 & 1901 & $+5 /-10$ \\
\hline 87140 & 67 & 455 & 35 & 1805 & $+10 /-8$ \\
\hline
\end{tabular}

${ }^{a}$ Total organic carbon fraction of samples was used for radiocarbon dating analyses

${ }^{\mathrm{b}}$ Radiocarbon ages were corrected by subtracting 300 yr of reservoir effect (Broecker and Walton, 1959). Corrected radiocarbon ages were converted into calendar ages through Table 2 in Stuiver et al. (1998) by selecting their most probable calendar years 


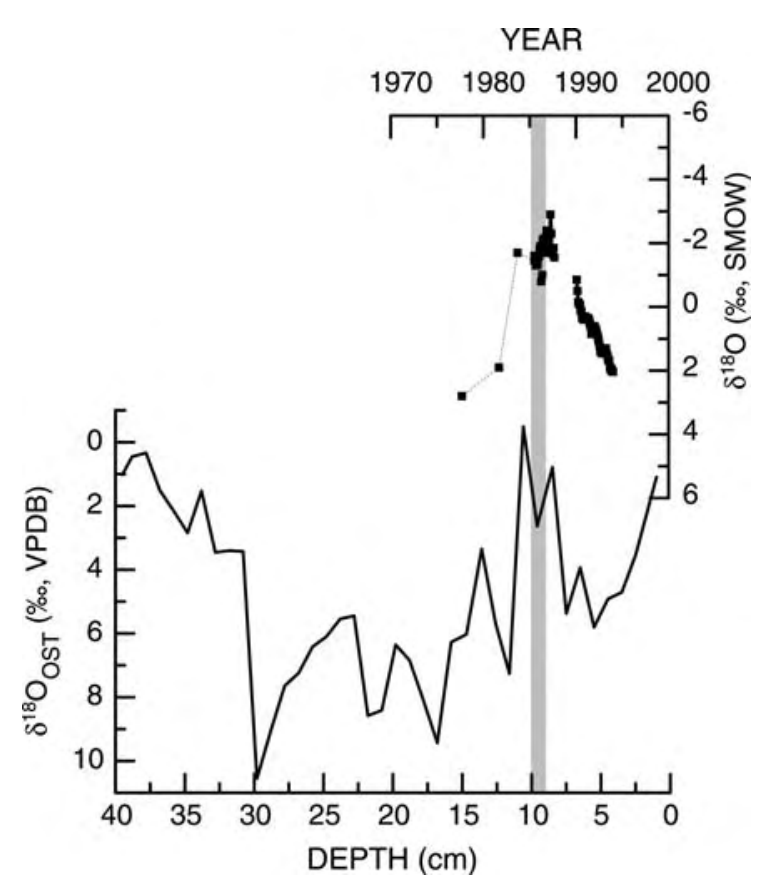

Fig. 6 Comparison of the 20-yr $\delta^{18} \mathrm{O}_{\text {water }}$ record with the $\delta^{18} \mathrm{O}_{\mathrm{OST}}$ record from WLB003C. Given the magnitude of isotopic variations, the two records are correlated. The $\delta^{18} \mathrm{O}$ of sediments at depth $\sim 9 \mathrm{~cm}$ can be associated with the central point ( $\sim 1986$ in age) of the water $\delta^{18} \mathrm{O}$ record, as highlighted by the vertical bar

\section{Discussion}

Understanding drought frequency and duration are important goals of lake sediment stable isotope studies of Holocene climate variability. However, the isotopic signature of downcore carbonate sediments is the result of various surface processes that are affected by a range of environmental variables (e.g., temperature, precipitation, evaporation, and water chemistry, etc.). Most of the surface processes related to these environmental variables are without doubt interlinked. Thus, it may be unrealistic to translate the $\delta^{18} \mathrm{O}_{\text {TIC }}$ or $\delta^{18} \mathrm{O}_{\mathrm{OST}} \mathrm{PDB}$ values into absolute or even relative values of a specific environmental variable without sufficient knowledge of a lake system (Leng and Marshall, 2004).

Instrumental lake-volume record and sporadic water-isotopic data

In Walker Lake, changes in lake level back to 1860 $\mathrm{AD}$ were instrumentally recorded by the U.S. Geological Survey (Benson, 1988). More importantly,
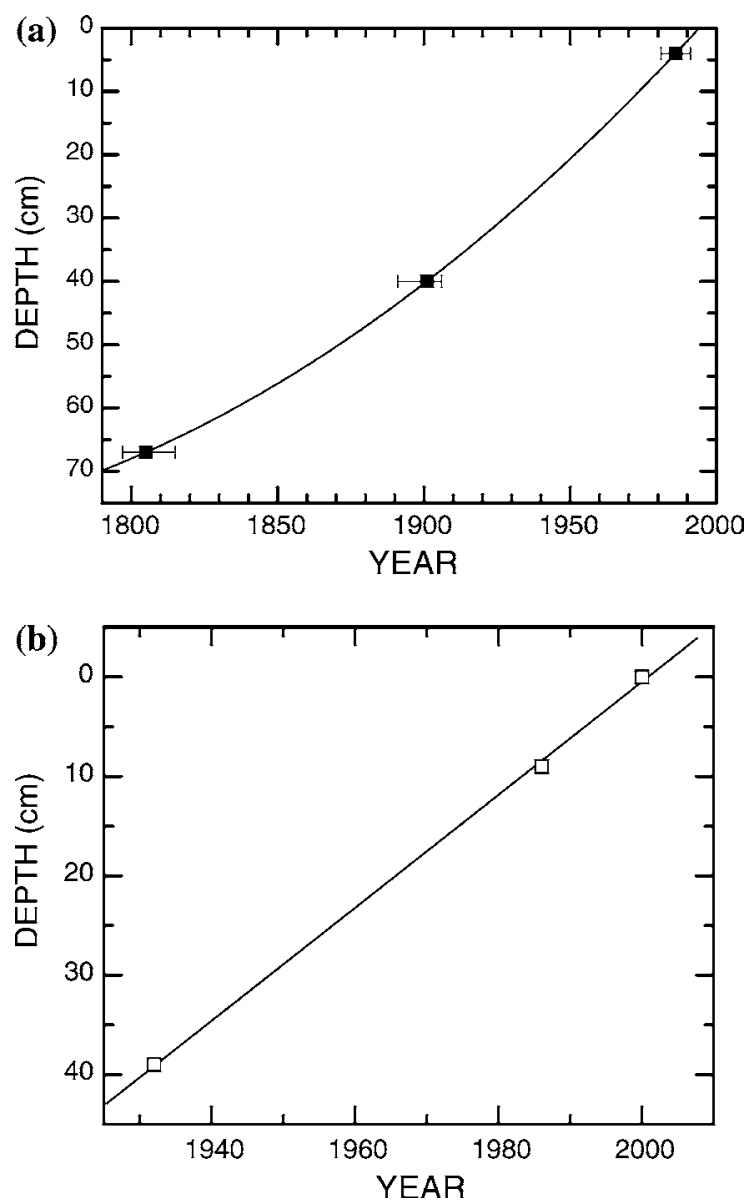

Fig. 7 Plots of calendar ages versus core depths. (a) Age model for core WLC002. The topmost age control is derived from correlations between lake sediment $\delta^{18} \mathrm{O}$ and $\delta^{18} \mathrm{O}_{\text {water }}$ records (ref. Fig. 6) and the rest age controls is determined through radiocarbon dating analysis of organic materials. Given the hard water effect (i.e., reservoir effect), the two radiocarbon dates were corrected by taking off $300 \mathrm{yr}$ of reservoir effect (Broecker and Walton, 1959) and then calibrated into calendar ages through Table 2 in Stuiver et al. (1998). A second-order polynomial fitting is used, year $=1992.4-1.5269$ depth $-0.01896 \mathrm{depth}^{2}$. (b) Age model for core WLB003C. Age controls are inferred from intra-core correlations between WLC002 and WLB003C (ref. Fig. 5). Linear age model equation, year $=2000.79-1.75779$ depth

as previously mentioned the isotope composition of lake water during the last few decades has been documented (Newton and Grossman, 1988; Benson et al., 1991, 1996). This provides a unique opportunity allowing us to closely examine the responses of core-based proxies to measured changes in Walker Lake's hydrologic balance. 


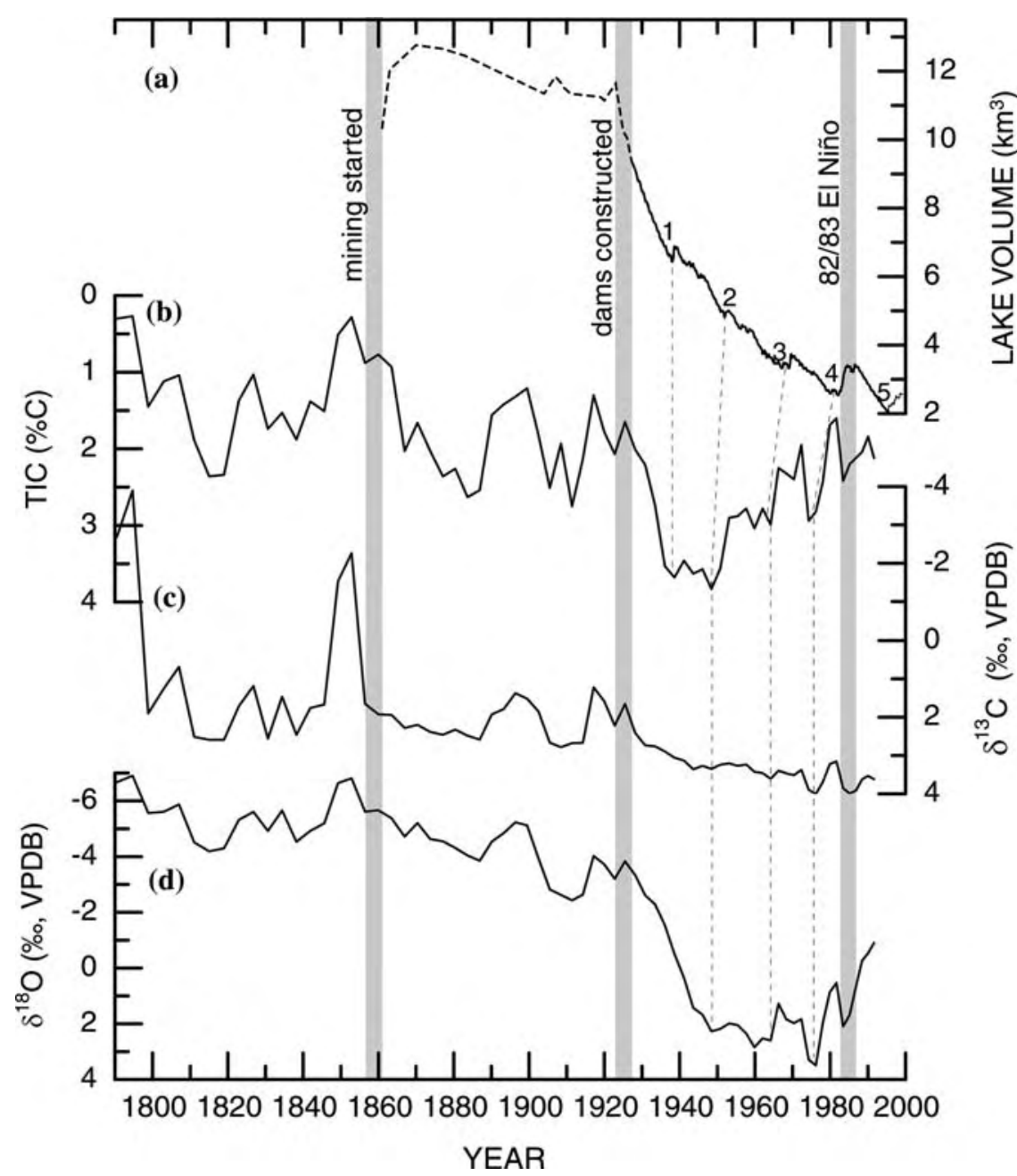

Fig. 8 Comparison of the instrumental record of Walker Lake volume with the $\% \mathrm{TIC}, \delta^{13} \mathrm{C}_{\mathrm{TIC}}$ and $\delta^{18} \mathrm{O}_{\mathrm{TIC}}$ records from core WLC002

The instrumental record of Walker Lake level contains nearly monthly-resolved measurements since later 1920s (Fig. 2 and Fig. 8a). The average lake volume and surface area between 1860 and 1920 is 11.7 and $276 \mathrm{~km}^{2}$ based on a few sporadic measurements and estimates (Fig. 8a). Assuming that annual on-lake precipitation and evaporation are 0.13 and $1.35 \mathrm{~m}$ (Milne, 1987; Yuan, 2003), the annual stream inflow of Walker Lake is estimated to be at least $0.303 \mathrm{~km}^{3}$ to maintain the size of the lake during the period 1860-1920. This is about 2 times the average annual stream inflow $\left(0.155 \mathrm{~km}^{3}\right.$, Yuan et al., 2004) during the last two decades. This inflow reduction from increasing irrigation demands and impoundments upstream beginning in the early 1920s lead to a rapid decrease in lake size (Benson and Leach, 1979). This decline in lake size is interrupted by approximately five "wet" events where lake level rose (Fig. 8a), some of which are associated with the El Niño Southern Oscillation (e.g., in 1982/83 and 1997/98).

The $\delta^{18} \mathrm{O}_{\text {water }}$ of Walker Lake was measured to be $2.8 \%$ (SMOW) in September 1977 (Newton and Grossman, 1988). Nearly monthly-resolved $\delta^{18} \mathrm{O}_{\text {water }}$ data were acquired between 1985 and 1987 and between 1990 and 1994 (Benson, 1988, 1991, 1996). The instrumental $\delta^{18} \mathrm{O}_{\text {water }}$ data of Walker Lake recorded substantial $(\sim 5 \%)$ changes in $\delta^{18} \mathrm{O}_{\text {water }}$ between 1977 and 1984 and between 1987 and 1994 (Fig. 9). Comparison with the instrumental lakevolume record shows that oscillations in $\delta^{18} \mathrm{O}_{\text {water }}$ 


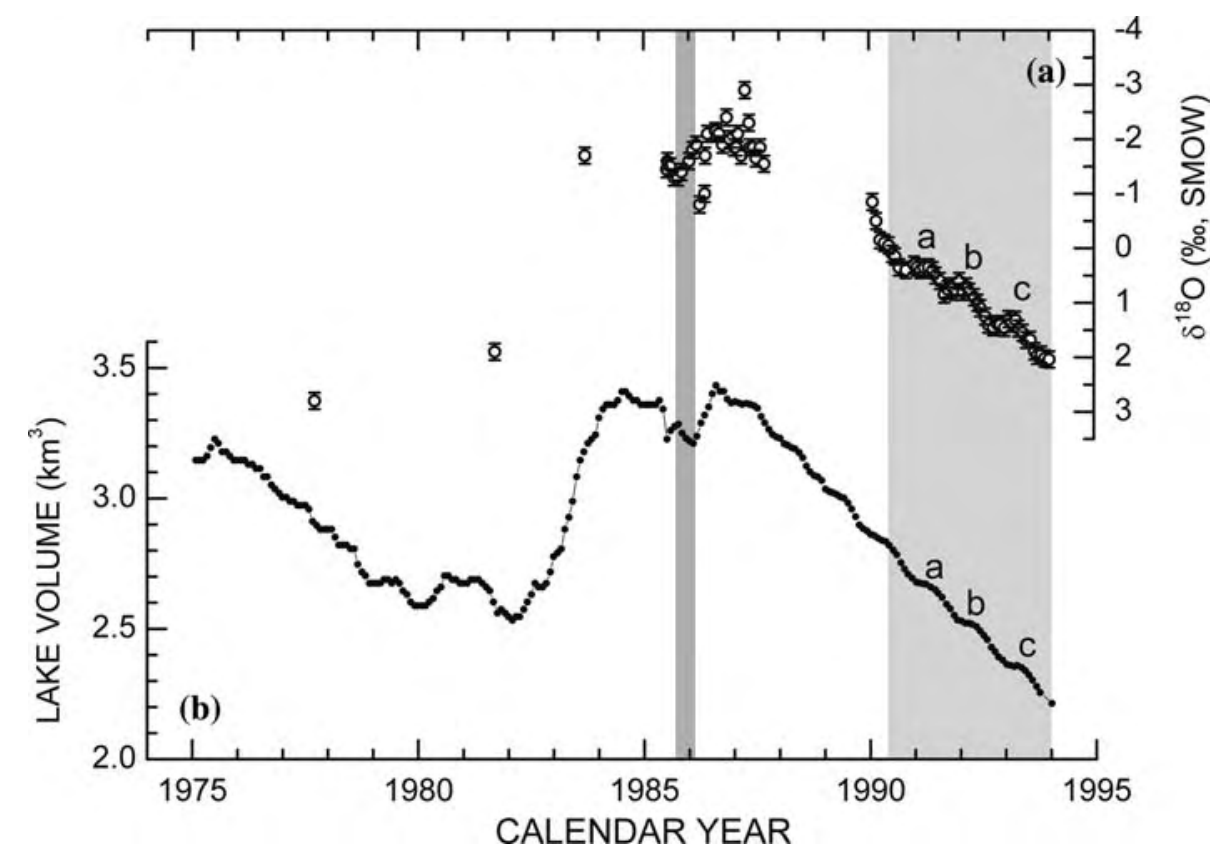

Fig. 9 Comparison of lake volume and $\delta^{18} \mathrm{O}_{\text {water }}$ records of Walker Lake spanning 1975-1994. Vertical gray bars highlight correlations between the two instrumental records. Note that three oscillations $(\mathrm{a}, \mathrm{b}$, and $\mathrm{c})$ in lake volume manifest well in

the $\delta^{18} \mathrm{O}_{\text {water }}$ record. Original lake volume data is from Benson (1988) and the $\delta^{18} \mathrm{O}_{\text {water }}$ data from Benson et al. $(1996,1991)$ and Newton and Grossman (1988)

generally track the lake-volume record on interannual and decadal time scales.

TIC and TOC

The \% TIC increased repeatedly in the intervals centered in $\sim 1810, \sim 1830, \sim 1870, \sim 1890$, and $\sim 1930$ (Fig. 8). The last increase coincided with the rapid decline in lake volume related to dam construction. It is not clear whether maxima in $\%$ TIC can be associated with minima in lake volume over the last $60 \mathrm{yr}$ due to the age uncertainties (Figs. 8a and 8b). However, the relationship between the \%TIC and lake volume has certainly been reversed since $\sim 1945$. This indicates that $\%$ TIC is not a simple function of lake volume. The $\% \mathrm{TIC}$ is determined by processes related to primary production and detrital dilution. In lake systems, \% TIC generally decreases when stream discharge increases because primary production is associated with dissolved calcium input that is a linear function of discharge while the mass of detrital input is likely an exponential function of discharge (Benson et al., 2002). The complex relationship of \% TIC and lake volume suggests

that primary production is also affected by other surface processes (e.g., deltaic process). Water chemistry results indicate that calcium was considerably depleted in Walker Lake during the last four decades (Table 1). This is because (1) dam operation reduces the flood frequency and the quantity of stream flow, (2) decreased inflow reduces calcium influx, and (3) a more regular flow reduces average flow velocity and increases the water residence time in the delta area where most of carbonates precipitate. On the other hand, dams upstream reduce not only the occurrence of flood, but also intercept stream detrital loadings. This explains why the \% TIC variability was relatively small over the last four decades compared to before 1960 (Figs. 8b and 10b).

To highlight the interannual to decadal timescale variability, the instrumental lake-volume record of Walker Lake during the last $70 \mathrm{yr}$ was detrended through removal of the long-term decreasing trend and compared with the high-resolution proxy results from WLB003C (Fig. 10). The detrended result is referred to here as lake level anomaly. There were approximately five droughts (labeled 1-5) centered in 1938, 1951, 1965, 1980 and 1995, only some of which appear 
Fig. 10 Comparison of normalized lake-volume anomaly with \% TOC, $\% \mathrm{TIC}, \delta^{13} \mathrm{C}_{\mathrm{TIC}}$ and $\delta^{18} \mathrm{O}_{\mathrm{TIC}}$ for core WLB003C. Normalized lake-volume anomaly was computed through removal of a long-term decreasing lake-level trend from the raw lake-volume record during the period 1930-2000

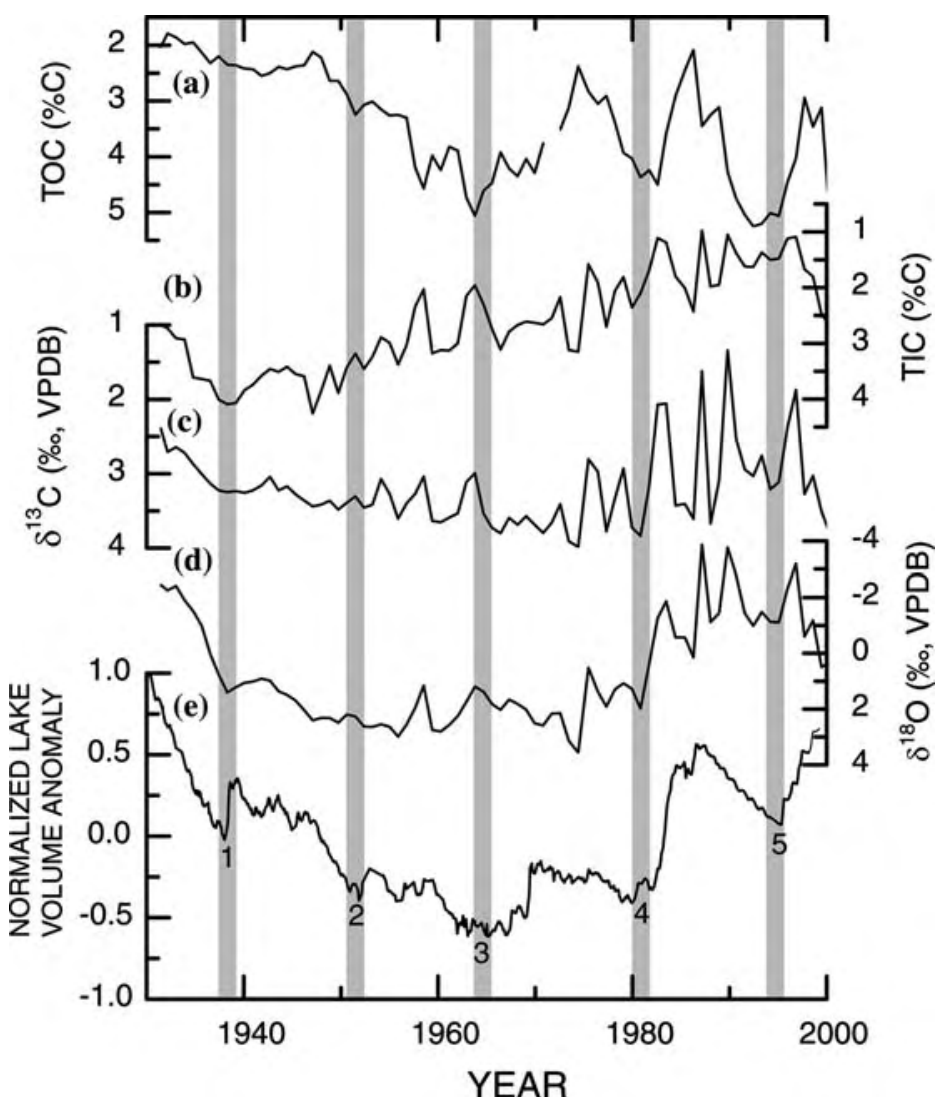

$\delta^{13} \mathrm{C}_{T I C}$ and $\delta^{18} \mathrm{O}_{T I C}$

5). In contrast, the \% TOC record correlates with the lake-volume anomaly. Four of the five lake-volume anomaly minima coincide with maxima in \% TOC (Fig. 10a, e). The \% TOC of Walker Lake sediments is determined by biological productivity, organic matter decomposition, and dilution by detrital materials (Benson et al., 1991). Today, the organic carbon in Walker Lake water is predominantly contained in the phytoplankton, mostly bluegreen algae (Nodularia spumigena) and diatoms (Koch et al., 1979; Beutel et al., 2001). The \%TOC increased progressively from 1930 to 1965 with the lake volume decreasing, and became more variable during the last four decades. Decreases in lake volume can lead to nutrient enrichment of lake water and vice versa (Benson et al., 1991). Three large decadal-timescale oscillations in \% TOC during the last four decades are likely related to changes in the lake's phytoplankton productivity resulting from relatively large changes in lake volume. $\delta^{13} \mathrm{C}_{\mathrm{TIC}}$ and $\delta^{18} \mathrm{O}_{\mathrm{TIC}}$ records from both WLB003C and WLC002 are significantly correlated with their respective \% TIC records $(p<0.01)$ (Figs. 8 and $10)$. Changes in isotopic composition of Walker Lake is usually interpreted to indicate changes in lake size (Benson et al., 1991). However, the large shifts $\left(4-6 \%\right.$ o in $\delta^{13} \mathrm{C}_{\mathrm{TIC}}$ that occurred in $\sim 1800$ and $\sim 1850$ (Fig. 8 ) are unlikely induced by hydrologic changes alone. The two $\delta^{13} \mathrm{C}_{\mathrm{TIC}}$ anomalies coincide with minima in \% TIC, suggesting that the bulk carbonate materials are likely dominated by calcareous faunal skeletons. The $\delta^{13} \mathrm{C}_{\mathrm{TIC}}$ record nearly parallels the $\delta^{18} \mathrm{O}_{\mathrm{TIC}}$ record and the lake-volume anomaly curve in the early parts of the record (prior to 1950 , see Figs. 8 and 10), but becomes more variable after 1980. This appears to be in part due to relatively large fluctuations in biological productivity and water chemistry resulting from the relatively small lake volume (Benson et al., 1991, 1996). 
Downcore $\delta^{18} \mathrm{O}_{\text {TIC }}$ in this setting appears to be the best indicator of past lake size because it nearly parallels the instrumental record of Walker Lake volume over the last $140 \mathrm{yr}$ (Fig. 8a, d). The relatively small amplitude variability in $\delta^{18} \mathrm{O}_{\mathrm{TIC}}$ prior to 1920 suggests the persistence of a relatively large lake $\left(>10 \mathrm{~km}^{3}\right)$. Rapid increases in $\delta^{18} \mathrm{O}_{\mathrm{TIC}}$ during the period 1920-1940 coincide with steep decreases in lake volume (Figs. $8 \mathrm{~d}$ and 10d). One explanation is that the evaporative process leads to enrichment of ${ }^{18} \mathrm{O}$ when lake volume is declining. The $\delta^{18} \mathrm{O}_{\mathrm{TIC}}$ remained near $2 \pm 1 \%$ between 1945 and 1970 even though the lake volume kept declining, and exhibited larger variability during the last three decades. This indicates that the $\delta^{18} \mathrm{O}_{\mathrm{TIC}}$ is also affected by other processes (e.g., lake geometric factors) rather than just hydrologic process. The $\delta^{18} \mathrm{O}_{\mathrm{TIC}}$ record from WLB003C also shows a great deal of similarity with the lake-volume anomaly data (Fig. 10d, e), but there exist a number of discrepancies between the two records. For example, some lake-volume minima appear to coincide with minima in $\delta^{18} \mathrm{O}_{\mathrm{TIC}}$ (labeled 2 and 3, see Fig. 10d, e). Considering the age uncer- tainties, most of changes in lake-volume anomaly could correlate with shifts in $\delta^{18} \mathrm{O}_{\mathrm{TIC}}$, but not all the variations in $\delta^{18} \mathrm{O}_{\mathrm{TIC}}$ can be associated with hydrologic fluctuations. This further suggests that at least some of the $\delta^{18} \mathrm{O}_{\mathrm{TIC}}$ variations are ascribed to nonhydrologic processes (e.g., chemical processes).

$\delta^{13} \mathrm{C}_{O S T}$ and $\delta^{18} \mathrm{O}_{O S T}$

Figure 11 shows changes in $\delta^{13} \mathrm{C}_{\mathrm{OST}}$ and $\delta^{18} \mathrm{O}_{\mathrm{OST}}$ in response to changes in the lake-volume anomaly during the last $70 \mathrm{yr}$. The $\delta^{13} \mathrm{C}_{\mathrm{OST}}$ increases substantially prior to 1960 and closely tracks the lakevolume anomaly record. This suggests that $\delta^{13} \mathrm{C}_{\mathrm{OST}}$ is, in part, related to hydrologic processes. However, the $\delta^{13} \mathrm{C}_{\text {OST }}$ maintained at the levels of $0 \pm 0.5 \%$ in the later part of the record (after 1960). This pattern of changes in $\delta^{13} \mathrm{C}_{\mathrm{OST}}$ appears to be similar to that of $\%$ TOC (compare Figs. 10a and 11a), suggesting that $\delta^{13} \mathrm{C}_{\mathrm{OST}}$ is more closely related to biological productivity than $\delta^{13} \mathrm{C}_{\mathrm{TIC}}$. The $\delta^{18} \mathrm{O}_{\mathrm{OST}}$ record mimics several sections of the lake-level anomaly curve, particularly for the recent two wet "events"
Fig. 11 Comparison of normalized lake-volume anomaly with $\delta^{13} \mathrm{C}_{\mathrm{OST}}$ and $\delta^{18} \mathrm{O}_{\mathrm{OST}}$ for core WLB003C

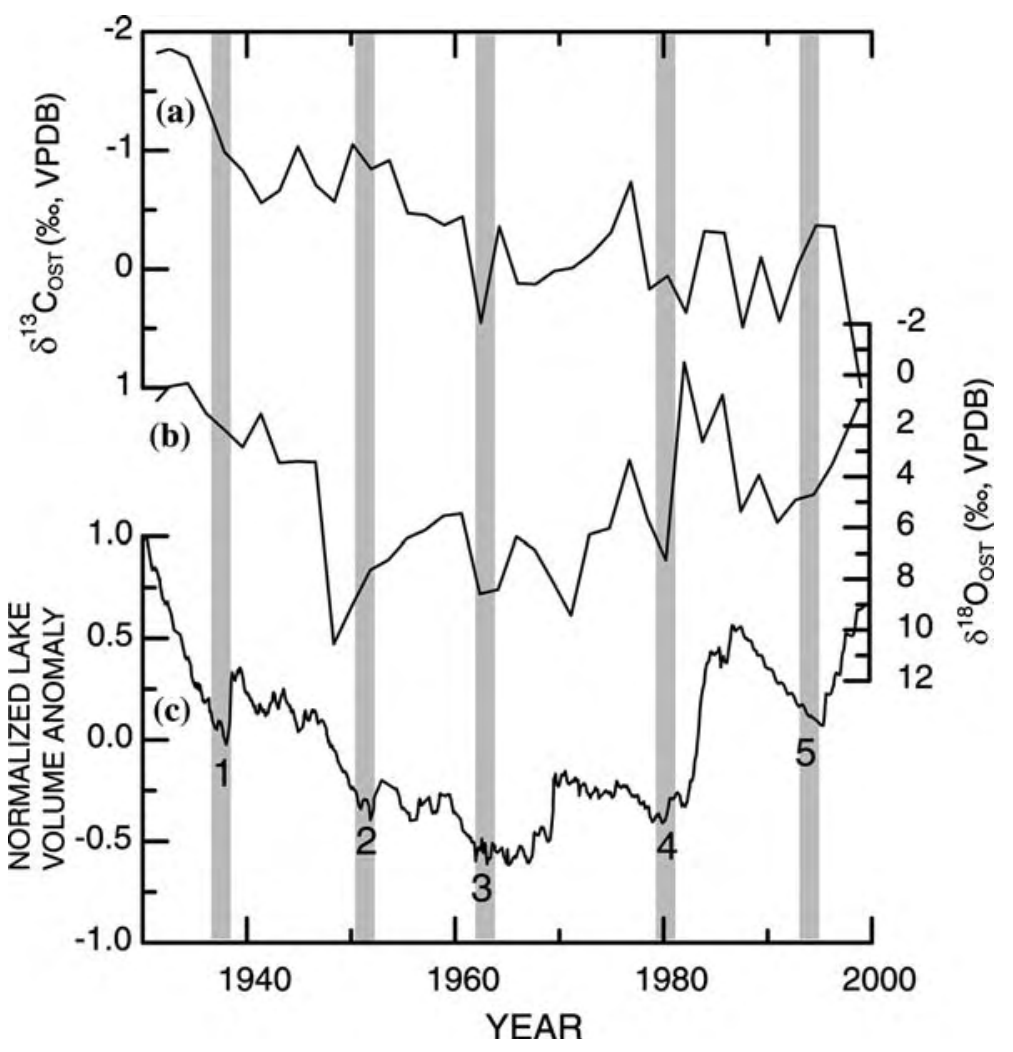


in the El Niño years of $1982 / 83$ and $1997 / 98$, as indicated by rapid lake-volume increases and concurrent $\delta^{18} \mathrm{O}_{\mathrm{OST}}$ decreases (Fig. 11b, c).

Comparison of the isotopic composition of lake waters and sediments

As previously noted, the Walker River receives significant runoff from Sierran snowmelt that has distinctly lower $\delta^{18} \mathrm{O}_{\text {water }}$ values $\quad(-13.8 \pm 1.05 \%$, SMOW) than Walker Lake water $(0.2 \pm 1.44 \%$, SMOW) (Table 2). Downcore carbonate sediments are enriched in ${ }^{18} \mathrm{O}$ compared to surface waters because of isotope fractionation during carbonate precipitation.
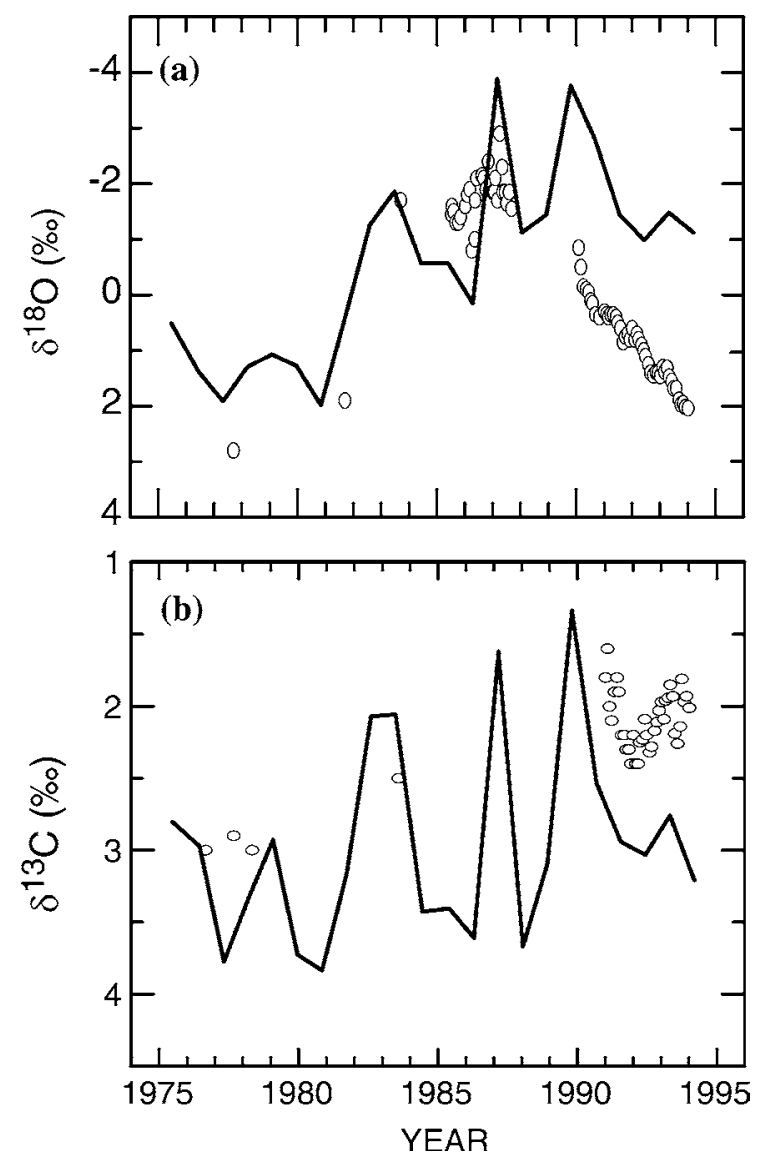

Fig. 12 Comparison of downcore sediment isotopic results with sporadic lake-water isotopic data spanning 1975-1995. (a) Comparison of $\delta^{18} \mathrm{O}_{\mathrm{TIC}}$ (solid line) and $\delta^{18} \mathrm{O}_{\text {water }}$ (open circles). Note that unit is in SMOW for $\delta^{18} \mathrm{O}_{\text {water }}$ and VPDB for $\delta^{18} \mathrm{O}_{\mathrm{TIC}}$. (b) $\delta^{13} \mathrm{C}_{\mathrm{TIC}}$ (solid line) and $\delta^{13} \mathrm{C}_{\mathrm{DIC}}$ (open circles). Unit is in VPDB. Lake-water isotopic data were taken from Benson (1988), Newton and Grossman (1988), Benson et al. (1991) and Benson et al. (1996)
The difference between the SMOW value of $\delta^{18} \mathrm{O}_{\text {water }}$ and the PDB value of $\delta^{18} \mathrm{O}_{\mathrm{TIC}}$ is on average $-1.9 \%$ for the period 1985-1994 (Table 2), which appears to be related to the thermodynamics of carbonate precipitation. On the basis of a modified version of the Craig paleotemperature equation (Kim and O'Neil, 1997; Leng and Marshall, 2004), $T=13.8-4.58\left(\delta_{c}-\delta_{w}\right)$ $+0.08\left(\delta_{c}-\delta_{w}\right)^{2}$, the average water temperature when Walker Lake carbonate forms is inferred to be $22.8^{\circ} \mathrm{C}$, in line with previous estimates (Galat and Jacobson, 1985; Benson et al., 1991). However, comparison of the $\delta^{18} \mathrm{O}_{\mathrm{TIC}}$ record with sporadic instrumental-based data of $\delta^{18} \mathrm{O}_{\text {water }}$ indicates that the isotopic difference between the two records changes over the time (Fig. 12a). The difference between the SMOW value of $\delta^{18} \mathrm{O}_{\text {water }}$ and the PDB value of $\delta^{18} \mathrm{O}_{\text {TIC }}$ was larger than $1.9 \%$ between 1990 and 1995, and less than $1.9 \%$ between 1977 and 1988. Some of the SMOW values of $\delta^{18} \mathrm{O}_{\text {water }}$ are close to and even more negative than the PDB values of $\delta^{18} \mathrm{O}_{\text {TIC }}$. The isotopic composition of carbonates decreases about $0.24 \%$ for each $1{ }^{\circ} \mathrm{C}$ increase in temperature (Craig, 1965), but such large variations in isotopic difference between the two records are unlikely to be caused by changes in water temperature alone. This suggests that carbonate precipitates may not always be in isotopic equilibrium with lake water and/or that the isotopic signature of carbonates has been altered through post-depositional processes. Today monohydrocalcite is the dominant carbonate precipitate in Walker Lake (Spencer, 1977). The oxygen isotope fractionation factor for monohydrocalcite- $\mathrm{H}_{2} \mathrm{O}$ is very close to that for calcite- $\mathrm{H}_{2} \mathrm{O}$ (Jimenez-Lopez et al., 2001), but monohydrocalcite is metastable and subject to recrystallization (Benson et al., 1991). Systematic calculations for isotope fractionation between calcite and aragonite (Zheng, 1999; Zhou and Zheng, 2003) suggest that calcite is likely to be enriched in ${ }^{18} \mathrm{O}$ by $4.5 \%$ relative to aragonite at $25^{\circ} \mathrm{C}$. The relatively small isotopic difference in the $\delta^{18} \mathrm{O}_{\text {water }}$ and $\delta^{18} \mathrm{O}_{\mathrm{TIC}}$ records between 1977 and 1986 is plausibly due to ${ }^{18} \mathrm{O}$ enrichment of downcore carbonate sediments resulting from isotope fractionation between calcite and monohydrocalcite.

The $\delta^{18} \mathrm{O}_{\mathrm{OST}}$ is, on average, $4.8 \%$ higher than the $\delta^{18} \mathrm{O}_{\text {TIC }}$ in the $70 \mathrm{yr}$ record. This appears to be caused by the $\delta^{18} \mathrm{O}$ vital effect observed in ostracodes (Xia et al., 1997) and the temperature difference between surface and bottom waters in the lake (Benson et al., 1991). This species of ostracode lives 
near the sediment-water interface at $6^{\circ} \mathrm{C}$ (Bradbury et al., 1989), whereas most inorganic carbonate precipitation occurs in the epilimnion when water temperature exceeds $\sim 22^{\circ} \mathrm{C}$ in late August or early September (Galat and Jacobson, 1985; Benson et al., 1991).

The $\delta^{13} \mathrm{C}$ value of dissolved inorganic carbon $\left(\delta^{13} \mathrm{C}_{\text {DIC }}\right)$ in the Walker River near Walker Lake was $-16 \%$ in 1979 (Peng and Broecker, 1980), whereas the $\delta^{13} \mathrm{C}_{\mathrm{DIC}}$ value of Walker Lake was on average $2.1 \%$ in the period from 1991 to 1994 (Benson et al., 1996). The $\delta^{13} C_{\text {DIC }}$ values of Walker Lake water are less variable compared to their corresponding $\delta^{18} \mathrm{O}$ values (Table 2). This is apparently due to the relatively large DIC pool in Walker Lake. The annual DIC input from the Walker River accounts for $\sim 0.4 \%$ of the total DIC in the lake, whereas the annual streamflow input accounts for $\sim 6 \%$ of the lake's water volume. The $\delta^{13} \mathrm{C}_{\mathrm{TIC}}$ values appear to be systematically more positive than the $\delta^{13} \mathrm{C}_{\text {DIC }}$ values (Fig. 12b). The $\delta^{13} \mathrm{C}_{\text {TIC }}$ was on average $0.9 \%$ more positive than $\delta^{13} \mathrm{C}_{\text {DIC }}$ between 1991 and 1994 (Table 2). This difference is within the range of equilibrium and kinetic fractionation effects during carbonate precipitation (Turner, 1982; Zhang et al., 1995). The $\delta^{13} \mathrm{C}_{\text {OST }}$ values were on average $3.0 \%$ o lower than the $\delta^{13} \mathrm{C}_{\mathrm{TIC}}$ between 1991 and 1994. This may also be in part induced by the vital effect of ostracodes (Benson et al., 1991).

\section{Carbon-oxygen isotopic covariance}

The covariance of $\delta^{13} \mathrm{C}_{\mathrm{TIC}}$ and $\delta^{18} \mathrm{O}_{\mathrm{TIC}}$ has been interpreted as evidence that both are hydrologic indicators in closed-basin lakes (Talbot, 1990; Li and $\mathrm{Ku}, 1997 \mathrm{a})$. However, records from semi-closed to open hydrological lakes also show covariance of $\delta^{13} \mathrm{C}$ and $\delta^{18} \mathrm{O}$ (Dean, 2002). Mechanisms controlling the carbon-oxygen isotopic covariance may differ from lake to lake. In Walker Lake, the surface lake water shows little correlation between $\delta^{13} \mathrm{C}_{\mathrm{DIC}}$ and $\delta^{18} \mathrm{O}_{\text {water }}$ based on 37 measurements during the period 1991-1994 by Benson et al. (1996). Measurements of the isotopic composition of sediment ostracode shells from this lake also show little correlation of $\delta^{13} \mathrm{C}_{\mathrm{OST}}$ and $\delta^{18} \mathrm{O}_{\mathrm{OST}}$ during the last 70 years. In contrast, $\delta^{13} \mathrm{C}_{\mathrm{TIC}}$ and $\delta^{18} \mathrm{O}_{\mathrm{TIC}}$ are positively correlated in the sediments of Walker Lake over the last $200 \mathrm{yr}$. This suggests that the values of $\delta^{13} \mathrm{C}_{\mathrm{TIC}}$ and $\delta^{18} \mathrm{O}_{\mathrm{TIC}}$ may not necessarily be representative of corresponding values of $\delta^{13} \mathrm{C}_{\mathrm{DIC}}$ and $\delta^{18} \mathrm{O}_{\text {water }}$. Comparison with sporadic instrumental results of $\delta^{13} \mathrm{C}_{\mathrm{DIC}}$ and $\delta^{18} \mathrm{O}_{\text {water }}$ indicates that there exist significant discrepancies between the two records (Fig. 12a, b). In the more recent interval between 1991 and 1994, the $\delta^{18} \mathrm{O}_{\text {water }}$ was more positive than $\delta^{18} \mathrm{O}_{\mathrm{TIC}}$, whilst the $\delta^{13} \mathrm{C}_{\mathrm{DIC}}$ was less positive than $\delta^{13} \mathrm{C}_{\text {TIC }}$.

There are basically two mechanisms proposed to explain the carbon-oxygen isotopic covariance, climatic forcing for temperate-region lakes (Drummond et al., 1995) and hydrological closure with very long residence time for arid-region lakes (Talbot and Kelts, 1990; Talbot, 1990). McKenzie (1982, 1985) proposed that carbonate sediments of Lake Greifen, Switzerland, became progressively more enriched in ${ }^{13} \mathrm{C}$ due to an increase in the removal rate of ${ }^{13} \mathrm{C}$ depleted organic matter of the epilimnion resulting from lake eutrophication. A negative water balance of a closed basin lake in arid-semiarid region leads to a reduction of lake volume and an increase in the $\delta^{18} \mathrm{O}_{\text {water }}$ and $\delta^{13} \mathrm{C}_{\mathrm{DIC}}$. However, the Lake Greifen model may be not applicable to Walker Lake due to lack of correlation between $\delta^{18} \mathrm{O}_{\text {water }}$ and $\delta^{13} \mathrm{C}_{\text {DIC }}$. Mees et al. (1998) argue that a simple linear covariance of $\delta^{13} \mathrm{C}$ and $\delta^{18} \mathrm{O}$ would not be expected if the $\delta^{13} \mathrm{C}_{\text {DIC }}$ were controlled by biological processes. We postulate that the observed covariance of $\delta^{13} \mathrm{C}_{\mathrm{TIC}}$ and $\delta^{18} \mathrm{O}_{\mathrm{TIC}}$ may be related to carbonate mineral chemistry, as both are positively correlated with \% TIC. Experimental data also indicate that both $\delta^{13} \mathrm{C}$ and $\delta^{18} \mathrm{O}$ of carbonate minerals decrease with increasing water carbonate concentration $\left[\mathrm{CO}_{3}^{2-}\right.$ ] (Spero et al., 1997). Change in water carbonate chemistry is likely to occur with water evaporation and $\mathrm{CO}_{2}$ outgassing.

\section{Summary and conclusions}

This study presents high-resolution multi-proxy records from Walker Lake spanning the last $200 \mathrm{yr}$. Comparison with the instrumental record back to 1860 allows us to closely examine changes in $\%$ TIC, \% TOC, and $\delta^{13} \mathrm{C}$ and $\delta^{18} \mathrm{O}$ in response to changes in lake volume. The results of this study suggest that all these proxies are either directly or indirectly associated with changes in lake volume, but that $\delta^{18} \mathrm{O}_{\mathrm{TIC}}$ is the most effective hydrologic 
indicator in this closed-basin lake as evidenced by the fact that the $\delta^{18} \mathrm{O}$ record from Walker Lake nearly parallels the instrumental record of lake level back to 1860 . This correlation is apparently due to the fact that (1) river water from snowmelt of the Sierra Nevada has distinctively lower values of $\delta^{18} \mathrm{O}$ than lake water, (2) $\delta^{18} \mathrm{O}$ of lake water is very sensitive to change in the lake's hydrologic balance (essentially stream discharge), and (3) $\delta^{18} \mathrm{O}$ of lake water is not affected by changes in the lake's phytoplankton productivity.

However, comparison of downcore isotopic records with sporadic instrumental data spanning 1965-1995 suggests that carbonate precipitates may not always be in isotopic equilibrium with lake water and/or that the isotopic composition of carbonates has been altered through post-depositional processes. The values of $\delta^{13} \mathrm{C}_{\mathrm{TIC}}$ and $\delta^{18} \mathrm{O}_{\mathrm{TIC}}$ may not be directly translated into absolute or even relative values of corresponding $\delta^{13} \mathrm{C}_{\mathrm{DIC}}$ and $\delta^{18} \mathrm{O}_{\text {water }}$. The observed covariance of $\delta^{13} \mathrm{C}_{\mathrm{TIC}}$ and $\delta^{18} \mathrm{O}_{\mathrm{TIC}}$ may have little connection with hydrologic closure or openness of a lake. The persistence of correlation between $\delta^{13} \mathrm{C}_{\mathrm{TIC}}$ and $\delta^{18} \mathrm{O}_{\mathrm{TIC}}$ suggests that both are regulated by change in water carbonate chemistry resulting from similar mechanisms (e.g., water evaporation and $\mathrm{CO}_{2}$ outgassing).

Downcore ostracode shells are relatively ${ }^{18} \mathrm{O}$-enriched and ${ }^{13} \mathrm{C}$-depleted compared with the isotope composition of lake water. This indicates that ostracode shells are not in isotopic equilibrium with lake water due to vital effect. The $\delta^{18} \mathrm{O}_{\mathrm{OST}}$ correlates with the lake-volume anomaly record and instrumental isotopic data, whilst the $\delta^{13} \mathrm{C}_{\mathrm{OST}}$ tends to be more closely related to biological productivity.

The results of this study suggest that the downcore $\delta^{18} \mathrm{O}_{\text {TIC }}$ contains some information about lake-level changes in Walker Lake over the last 200 yr. However, it appears that not all of the variations in $\delta^{18} \mathrm{O}_{\text {TIC }}$ are necessarily caused by hydrologic changes due to the complex nature of the lake system. This indicates that caution must be taken when interpreting isotopic results from similar lake settings.

Acknowledgements We are indebted to L. Benson for his supervision of core collection, thoughtful ideas and discussions, and review of an early version of this manuscript. We thank S. Lund, J. Smoot, A. Heyvaert and B. Richards for field assistance in core collection, and D. Rodbell for analytical assistance.

\section{References}

Benson L (1988) Preliminary paleolimnological data for the Walker Lake Subbasin, California and Nevada, U.S. Geological Survey, Water-Resources Investigations Report 87-4258, Boulder, CO, 50 pp

Benson L (1999) Records of millennial-scale climate change from the Great Basin of the western United States. In: Clark PU, Webb RS, Keigwin LD (eds) Mechanisms of global climate change at millennial time scales. Geophysical monograph 112. AGU, Washington, DC, pp 203-225

Benson L, Linsley B, Smoot J, Mensing S, Lund S, Stine S, Sarna-Wojcicki A (2003) Influence of the Pacific Decadal Oscillation on the climate of the Sierra Nevada, California and Nevada. Quat Res 59:151-159

Benson L, Lund S, Paillet F, Smoot J, Kester C, Mensing S, Meko D, Lindström S, Kashgarian M, Rye R (2002) Holocene multidecadal and multicentennial droughts affecting Northern California and Nevada. Quat Sci Rev 21:659-682

Benson L, Paillet F (2002) HIBAL: a hydrologic-isotopicbalance model for application to paleolake systems. Quat Sci Rev 21:1521-1539

Benson L, White LD, Rye R (1996) Carbonate deposition, Pyramid Lake Subbasin, Nevada: 4. Comparison of the stable isotope values of carbonate deposits (tufas) and the Lahontan lake-level record. Palaeogeogr Palaeoclimatol Palaeoecol 122:45-76

Benson LV, Leach DL (1979) Uranium transport in the Walker River Basin, California and Nevada. J Geochem Explor 11:227-248

Benson LV, Meyers PA, Spencer RJ (1991) Change in the size of Walker Lake during the past 5000 years. Palaeogeogr, Palaeoclimatol, Palaeoecol 81:189-214

Benson LV, Spencer RJ (1983) A hydrochemical reconnaissance study of the Walker River Basin, California and Nevada, $53 \mathrm{pp}$

Beutel MW, Horne AJ, Roth JC, Barratt NJ (2001) Limnological effects of anthropogenic desiccation of a large, saline lake, Walker Lake, Nevada. Hydrobiologia 466: 91-105

Bradbury JP (1987) Late Holocene diatom paleolimnology of Walker Lake, Nevada. Arch Hydrobiol/Suppl 79:1-27

Bradbury JP, Forester RM, Thompson RS (1989) Late Quaternary paleolimnology of Walker Lake, Nevada. J Paleolimnol 1:249-267

Broecker WS, Walton AF (1959) The geochemistry of ${ }^{14} \mathrm{C}$ in freshwater systems. Geochim Cosmochim Acta 16:15-38

Cooper JJ, Koch DL (1984) Limnology of a desertic terminal lake, Walker Lake, Nevada, USA. Hydrobiologia 118:275-292

Covich A, Stuiver M (1974) Changes in oxygen 18 as a measure of long-term fluctuations in tropical lake levels and molluscan populations. Limnol Oceanogr 19:682-691

Craig H (1965) The measurement of oxygen isotope paleotemperatures. In: Tongiorgi E (eds) Stable isotopes in oceanographic studies and paleotemperature. Consiglio Nazionale delle Richerche, Laboratorio de Nucleare, Pisa, Italy, pp 161-182 
Dean W (2002) A 1500-year record of climatic and environmental change in Elk Lake, Clearwater County, Minnesota II: Geochemistry, mineralogy, and stable isotopes. J Paleolimn 27:301-319

Drummond CN, Patterson WP, Walker JCG (1995) Climate forcing of carbon-oxygen isotopic covariance in temperate-region marl lakes. Geology 23:1031-1034

Engleman EE, Jackson LL, Norton DR (1985) Determination of carbonate carbon in geological materials by coulometric titration. Chem Geol 53:125-128

Fritz P, Poplawsk S (1974) O-18 and C-13 in shells of freshwater mollusks and their environments. Earth Planet Sci Lett 24:91-98

Galat DL, Jacobson RL (1985) Recurrent aragonite precipitation in saline-alkaline Pyramid Lake, Nevada. Arch Hydrobiol/Suppl 105:137-159

Holmes JA (1996) Trace-element and stable-isotope geochemistry of non-marine ostracod shells in Quaternary palaeoenvironmental reconstruction. J Paleolimn 15: 223-235

Horn LH, Bryson RA (1960) Harmonic analysis of the annual march of precipitation over the United States. Ann Assoc Amer Geogr 50:157-171

Jellison R (1996) Organic matter accumulation in sediments of hypersaline Mono Lake during a period of changing salinity. Limnol Oceanogr 41:1539-1544

Jimenez-Lopez C, Caballero E, Huertas FJ, Romanek CS (2001) Chemical, mineralogical and isotope behavior, and phase transformation during the precipitation of calcium carbonate minerals from intermediate ionic solution at $25^{\circ} \mathrm{C}$. Geochim Cosmochim Acta 65:3219-3231

Kim ST, O’Neil JR (1997) Equilibrium and nonequilibrium oxygen isotope effects in synthetic carbonates. Geochim Cosmochim Acta 61:3461-3475

Kirby ME, Poulsen CJ, Lund SP, Patterson WP, Reidy L, Hammond DE (2004) Late Holocene lake level dynamics inferred from magnetic susceptibility and stable oxygen isotope data: Lake Elsinore, southern California (USA). J Paleolimnol 31:275-293

Koch DL, Cooper JJ, Lider EL, Jacobson RL, Spencer RJ (1979) Investigations of Walker Lake, Nevada: dynamic ecological relationships. University of Nevada, Reno, NV, $191 \mathrm{pp}$

Leng MJ, Marshall JD (2004) Palaeoclimate interpretation of stable isotope data from lake sediment archives. Quat Sci Rev 23:811-831

Li HC, Ku TL (1997a) $\delta^{13} \mathrm{C}-\delta^{18} \mathrm{O}$ covariance as a paleohydrological indicator for closed-basin lakes. Palaeogeogr Palaeoclimatol Palaeoecol 133:69-80

Li H-C, Ku T-L (1997b) Decadal hydroclimatic variability in the western coastal United States: Temporal and spatial variations in precipitation, streamflow and lake level. In: Tharp VL (ed) Proceedings of 13th Annual Pacific Climate (PACLIM) Workshop, April 15-18, 1996. Interagency Ecological Program, Technical Report 53. California Department of Water Resources, pp. 79-91

Li HC, Ku TL, Stott LD, Anderson RF (1997) Stable isotope studies on Mono Lake (California). $1 \delta^{18} \mathrm{O}$ in lake sediments as proxy for climatic change during the last 150 years. Limnol Oceanogr 42:230-238
Li HC, Stott LD, Bischoff JL, Ku TL, Lund SP (2000) Climate variability in East-Central California during the past 1000 years reflected by high-resolution geochemical and isotopic records from Owens Lake sediments. Quat Res 54:189-197

Mantua NJ, Francis RC, Hare SR, Zhang Y, Wallace JM (1997) A Pacific interdecadal climate oscillation with impacts on salmon production. Bull Am Meteorol Soc 78:1069-1079

Mantua NJ, Hare SR (2002) The Pacific Decadal Oscillation. J Oceanogr 58:35-44

McKenzie JA (1982) Carbon-13 cycle in Lake Greifen: a model for restricted ocean basins. In: Schlanger SO, Cita MB (eds) Nature and origin of cretaceous carbon-rich facies. Academic Press, London, UK, pp. 197-207

McKenzie JA (1985) Carbon isotopes and productivity in the lacustrine and marine environment. In: Stumm W (ed) Chemical processes in lakes. Wiley, New York, pp 99-118

Mees F, Reyes E, Keppens E (1998) Stable isotope chemistry of gaylussite and nahcolite from the deposits of the crater lake at Malha, northern Sudan. Chem Geol 146:87-98

Miller MR, Hardman G, Mason HG (1953) Irrigation waters of Nevada, Nevada University of Agriculture Experiment Station Bulletin 187, 63 pp

Milne W (1987) A comparison of reconstructed lake-level records since the mid-1800s of some Great Basin lakes. M.Sc. Thesis. Colorado School of Mine, Golden, Colorado, $207 \mathrm{pp}$

NDEP (2004) State of Nevada Surface Water Monitoring Network: Walker River Basin (http://ndep.nv.gov/bwqp/ WalkerMap.html). Nevada Division of Environmental Protection, Carson City, Nevada

Newton MS, Grossman EL (1988) Late Quaternary chronology of tufa deposits, Walker Lake, Nevada. J Geol 96:417433

Peng TH, Broecker W (1980) Gas exchange rates for three closed-basin lakes. Limnol Oceanogr 25:789-796

Redmond KT, Koch RW (1991) Surface climate and streamflow variability in the western United States and their relationship to large-scale circulation indices. Water Resour Res 27:2381-2399

Riehl H, Alaka MA, Jordan CL, Renard RJ (1954) The jet stream. Meteorol Monogr 2:23-47

Rush FE (1970) Hydrologic regime of Walker Lake, Mineral County, Nevada. US Geol Surv Hydrol Atlas, HA415

Russell IC (1885) Geological history of Lake Lahontan, a Quaternary lake of northwestern Nevada US Geological Survey Monograph 11, 288 pp

Spencer RJ (1977) Silicate and carbonate sediment-water relations in Walker Lake, Nevada. M.Sc. Thesis. University of Nevada, Reno, Nevada, 98 pp

Spero HJ, Bijma J, Lea DW, Bernis BE (1997) Effect of seawater carbonate concentration on foraminiferal carbon and oxygen isotopes. Nature 390:497-500

Stuiver M (1968) Oxygen-18 content of atmospheric precipitation during the last 11,000 years in the Great Basin region. Science 162:994-997

Stuiver M (1970) Oxygen and carbon isotope ratios of fresh water carbonates as climatic indicators. J Geophys Res $75: 5247-5257$ 
Stuiver M, Reimer PJ, Braziunas TF (1998) High-precision radiocarbon age calibration for terrestrial and marine samples. Radiocarbon 40:1127-1151

Talbot MR, Kelts K (1990) Paleolimnological signatures from carbon and oxygen isotopic ratios in carbonates from organic carbon-rich lacustrine sediments. In: Katz BJ (ed) Lacustrine basin exploration-case studies and modern analogs. AAPG Memoir 50, pp 99-112

Talbot MRA (1990) A review of the palaeohydrological interpretation of carbon and oxygen isotopic ratios in primary lacustrine carbonates. Chem Geol 80:261-280

Turner JV (1982) Kinetic fractionation of carbon-13 during calcium carbonate precipitation. Geochim Cosmochim Acta 46:1183-1191

Ware DM, Thomson RE (2000) Interannual to multidecadal timescale climate variations in the Northeast Pacific. J Clim 13:3209-3220

Xia J, Ito E, Engstrom DR (1997) Geochemistry of ostracode calcite: part 1. An experimental determination of oxygen isotope fractionation. Geochim Cosmochim Acta 61:377382
Yuan F (2003) Late Holocene hydrologic and climatic variability in the Walker Lake Basin, Nevada and California. Ph.D. Thesis. University at Albany, Albany, New York, $167 \mathrm{pp}$

Yuan F, Linsley B, Lund S, McGeehin J (2004) A 1200 year record of hydrologic variability in the Sierra Nevada from sediments in Walker Lake, Nevada. Geochem Geophys Geosyst 5:doi:10.1029/2003GC000652

Zhang J, Quay PD, Wilbur DO (1995) Carbon isotope fractionation during gas-water exchange and dissolution of $\mathrm{CO}_{2}$. Geochem Cosmochim Acta 59:107-114

Zhang Y, Wallace JM, Battisti DS (1997) ENSO-like Interdecadal Variability: 1900-93. J Clim 10:1004-1020

Zheng YF (1999) Oxygen isotope fractionation in carbonate and sulfate minerals. Geochem J 33:109-126

Zhou G-T, Zheng Y-F (2003) An experimental study of oxygen isotope fractionation between inorganically precipitated aragonite and water at low temperatures. Geochim Cosmochim Acta 67:387-399 